\title{
Urrutiko hezkuntza. \\ COVID-19aren eragina Bigarren Hezkuntzan
}

\author{
Distance Education. \\ The impact of COVID-19 on Secondary Education
}

\author{
Ainhize Gamarra* \\ Hezkuntza, Filosofia eta Antropologia Fakultatea \\ Euskal Herriko Unibertsitatea, Donostia, Gipuzkoa
}

LABURPENA: Artikulu honek urrutiko hezkuntzara bat-batean aldatzeak hezkuntza kalitatean izan duen eragina ikerketzea du helburu, hain zuzen ere Bigarren Hezkuntzan (DBH eta Batxilergoan) EAEn. COVID-19aren pandemia dela eta, ikasketa-zentro guztiak itxi eta biztanleria etxean konfinatuta egon behar izan denez, urrutiko hezkuntza beharrezkoa bihurtu da. Bigarren Hezkuntzako ikasleek eta irakasleek beti hezkuntza presentzialean lan egin dute, eta ez dute inoiz urrutiko hezkuntzarekin aurreko kontakturik izan, salbuespen gutxi izan ezik. Horregatik, urrutiko hezkuntzara egokitzeko prozesua eta haren ondorioak aztertuko dira, eta lortutako emaitzak eta ondorioak erakutsiko. Era horretan, hezkuntza kalitatean izandako eragina ezagutzeko, adierazitako egoera aztertzen da, bai ikasleen, bai irakasleen ikuspuntutik metodologia kuantitatiboa eta kualitatiboa erabiliz.

GAKO-HITZAK: urrutiko hezkuntza, irakaskuntza, ikaskuntza, bigarren hezkuntza, aldaketa.

ABSTRACT: This article is a research whose objective is to study the impact of the sudden change from on-site education to distance education on the educative quality, namely on Secondary Education in the Autonomous Community of the Basque Country. As a consequence of the COVID-19 pandemic, distance education turned into a necessity, due to the closure of schools and population's confinement. Secondary Education's teachers and students have always worked on on-site education, no having previous contact with distance education, with the exception of few cases. For this reason, it is analyzed the impact on educational quality and its consequences, showing the results and conclusions obtained. In this way, it is studied the experimented situation from the point of view of both teachers and students using quantitative and qualitative methodology.

KEYWORDS: distance education, teaching, learning, secondary education, change.

* Harremanetan jartzeko / Corresponding author: Ainhize Gamarra. UPV/EHU. Itsasketa Zientzia eta Teknikak, Itsasontzi Ma-
kinak eta Itsasongintza Saila. María Díaz de Haro kalea, 68 (48920 Portugalete). - ainhize.gamarra@ehu.eus - https://orcid.
org/0000-0002-1433-2984 Nola aipatu / How to cite: Gamarra, Ainhize (2021). «Urrutiko hezkuntza COVID-19aren eragina Bigarren Hezkuntzan». Tantak, 33(1), 43-82. (https://doi.org/10.1387/tantak.21841).

Jasotze-data: 2020/06/24; Onartze-data: 2020/12/03

ISSN 0214-9753 - elSSN 2444-3581 / (C) 2021 UPV/EHU

(c) (i) (-) Lan hau Creative Commons Aitortu-EzKomertziala-LanEratorririkGabe 4.0 Nazioartekoa

lizentzia baten mende dago 


\section{IKERKETA LANAREN AURKEZPENA}

Koronabirus mota berria (SARS-CoV-2), COVID-19 deiturikoa lehen aldiz Wuhanen (Txina) 2019ko abenduaren bukaeran ezagutu zen. Gaixotasuna azkar hedatu da mundu osotik, pandemia izatera ailegatuta.

Gure herrialdera ailegatu eta hainbat lagun kutsatu ostean, Eusko Jaurlaritzak Euskal Autonomia Erkidegoko (EAE) hezkuntza-zentro guztiak ixtea erabaki zuen, COVID-19ri aurre egin ahal izateko. Neurri horren bidez, kutsatze berriak saihestu nahi ziren, gaixotasunaren transmisioa galaratzeko euste fasea bultzatuz.

Hori dela eta, ikastetxeetako eskola presentzialak bertan behera utzi egin behar izan dira. Lehenik, Gasteiz eta Arabar errioxako ikasketa-zentroetan (2020/03/10); bigarrenik, Arabako eta Balmasedakoetan (Bizkaia) (2020/03/12); eta azkenik, EAE osoko ikasketa-zentroetan (2020/03/13). Ondoren, Espainiako Gobernuak Alarma Egoera dekretatu zuen (2020/03/16), eta biztanleriaren konfinamendua agindu, baita Estatuaren ikastetxe guztien itxiera ere (Eitb-ko erredakzioa, 2020) (López, 2020).

Hortaz, EAEn COVID-19aren pandemia dela eta, ikasketa-zentro guztiak itxi eta biztanleria etxean konfinatuta egon behar denez, urrutiko hezkuntza beharrezkoa bilakatu da. Ikasleek eta irakasleek beti hezkuntza presentzialean lan egin dute, eta ez dute inoiz urrutiko hezkuntza erabili, salbuespen gutxi izan ezik. Horregatik, urrutiko hezkuntzara egokitzeko prozesuak heziketa erabat aldatu du: metodologia, komunikazioa, klaseak emateko era, ebaluazioa, ikasleen jarrera...

Hezkuntza presentziala jatorrizkoa izanda eta aldez aurretik urrutiko hezkuntzarekin kontakturik ez zela, bat-batean urrutiko hezkuntzara salto egin beharrak Bigarren Hezkuntzan izugarrizko eragina izan du. Urrutiko hezkuntza hemen guztiz berria izan arren, beste zenbait tokitan arrunta da (2. Oinarri teorikoa atalan aztertzen denez); adibidez, Australian «Aire Eskola» deituriko hezkuntza dago, non urrutiko arrantxoetan bizi diren ikasleek ikasi ahal izateko, irrati bidez eskolak ematen diren, elkarrekintza bultzatuz.

Hori guztia kontuan hartuta, hezkuntza arloan bizi izandako egoera berria ikertzea da artikulu honen helburua; hain zuzen ere, urrutiko hezkuntzara bat-batean salto egin behar izateak Bigarren Hezkuntzan izan duen eragina.

\section{OINARRI TEORIKOA}

Hezkuntza ez-presentziala izendatzeko hainbat termino erabiltzen dira, hala nola, «urrutiko hezkuntza» (educación a distancialdistance education), «urrutiko ikaskuntza» (aprendizaje a distancia/distance learning), «urrutiko irakaskuntza» (enseñanza a distancia/distance 
teaching) edo «hezkuntza irekia»(educación abierta/open education). Gaur egungo urrutiko hezkuntzaren joera Interneten bidez gauzatzea denez, era horretan ematen denean hurrengo termino hauekin ere izendatzen da: «hezkuntza birtuala» (educación virtual/virtual education), «e-hezkuntza»(e-educación/e-education), «e-ikaskuntza»(e-aprendizaje) e-learning), «mugikorraren bidezko ikaskuntza elektronikoa» (m-aprendizaje/m-learning)...

Ikerketa arloa zeharo landuta egonda ere, ez dago hiztegi partekaturik adituen artean; erabilitako terminoak eta horien esanahia autoreen araberakoa izaten dira. Gainera, askotan autoreek euren lanetan ez dute zehazten haien definizioa, terminoaren unibertsitaltasuna jakintzat emango balitz bezala jokatuz edo arazoa kontuan hartu barik (King eta Schrader, 2001).

Aditu teorikoei ezinezkoa egin zaie «urrutiko hezkuntza», «urrutiko ikaskuntza» edo «urrutiko irakaskuntza» terminoen unibertsalki adostutako definizio bat topatzea hainbat faktorerengatik: teknologiak aurrera egin heinean, terminoak bilakatuz doazelako (Phipps eta Merisotis, 1999), guztiek ez dutelako antzeko era batean ulertzen «urruti» terminoa zer den (García, 2002), terminoen erabilera malgua (Moore, Dickson-Deane eta Galyen, 2011)...

Hala eta guztiz ere, «urrutiko hezkuntza», «urrutiko ikaskuntza» edo «urrutiko irakaskuntza» terminoen arteko ezberdintasuna aztertzeko, «urruti» hitza laguntzen duten terminoen definizioak ezagutzea beharrezkoa da. Harluxet hiztegi entziklopedikoak honela definitzen ditu (Harluxet, 2001):

- Ikaskuntza: «Ikasteko ekintza eta horren ondorioa, bereziki ezagutzak edo gaitasunak nork bere egiteko prozesua.»

- Irakaskuntza: «Irakasteko ekintza eta horren ondorioa; irakastesistema hornitzen duen bitarteko, bide eta pertsonen multzoa.»

- Hezkuntza: «Gizakia, bere ahalmenak garatuz eta gizabidea erakutsiz, gizartean bizitzeko prestatzea eta gaitzea, eta horretarako erabiltzen diren bideak edo sistemak.»

Ondorioz, garatutako ekintzak zehazten du termino baten edo bestearen erabilera, hain zuzen ere, ezagutzak jasotzea (ikastea) edo ezagutzak transmititzea (irakastea). Hori dela eta, noren ikuspuntutik gertatzen ari den da gakoa «ikaskuntza» edo «irakaskuntza» terminoa aukeratzeko. Beraz, «ikaskuntza» ikaslearen ikuspuntutik izango liteke; «irakaskuntza», ordea, irakaslearen ikuspuntik. «Hezkuntza»-ri dagokionez, termino orokorra da, bi ekintzak batzen dituena, hots, ikasle eta irakaslearena.

Diccionario de términos clave de ELE hiztegian Cervantes Institutu-ak (Institutu Cervantes, d. g.) «enseñanza a distancia», hots, «urrutiko irakaskuntza», ikasleek euren bizilekutik ikasketak jarraitzen duten ikaskuntza mota bezala definitzen du, ikasketa-zentrora joan behar barik edo bakarrik noizean behin joanda. Horretan, materialak eskuratzen dira tresna ezberdi- 
nen bidez, teknologiaren eta komunikazioa medioen aurrerapenekin bilakatu egin dena. Aipatu beharra dago ez dagoela sarrerarik beste bi terminoak adierazteko.

Cervantes Institutu-ak adierazitako definizioa ardatz hartuko da artikulu honetan zehar «urrutiko irakaskuntza», «urrutiko ikaskuntza» edo «urrutiko hezkuntza» terminoak erabiltzean; eta behin «Harluxet Hiztegi Entziklopedia»-n aztertutako definizioak ezaguta, hiruren artean, «urrutiko hezkuntza» terminoa erabiliko da, bai irakaste, bai ikaste prozesuak biltzen direlako eta ikerketa lan honen helburua hezkuntza mota horren eragina ikasle eta irakasleengan aztertzea delako.

«Hezkuntza irekia» eta «urrutiko hezkuntza»-ren arteko ezberdintasunaren inguruan ere nahasketa handia dago. Arestian esan bezala, hezkuntza ez-presentziala izendatzeko «hezkuntza irekia» terminoa askotan erabiltzen da, baita «irekia» izenondoa ere gehitzen ohi da beste terminoei heziketa era horrekiko lotura duela adierazteko. Terminoaren erabilerak 1969an Erresuma Batuan sortutako hezkuntza ez-presentzialaren unibertsitate publikoan du jatorria, British Open University deiturikoa (Holmberg, 2005). Unibertsitate hori aitzindaria izan zen, eta mundu mailan goi-mailako graduak urrutian ikasteko lehen ikasketa-zentro ofiziala ere bai (Bates, 1999).

Hori dela eta, «hezkuntza irekia» terminoa «urrutiko hezkuntza»-ren baliokidetzat hartzen ohi da zenbait autoreentzat, horien artean Mary Thorpek argudiatzen du «posta bidezko hezkuntza» gaindituta izan dela, eta «urrutiko hezkuntza» terminoaz ordeztua, eta hori ere gainditua izan dela, eta «ikaskuntza irekia»-terminoak ordeztua (Holmberg, 2005). Hala ere, autore batzuk ez dira bat etortzen halako baieztapenekin. Bi terminoen esanahia ezberdintzat hartzen dutenen artean definizioak antzekoak izaten dira.

- «Hezkuntza irekia»-k egitura aldaketarekin lotura dauka; hain zuzen ere, instituzioa irekia egiteko aldaketak adierazten ditu: lekuari, denbora kudeaketari, edukiei, ikaste metodologiari... begira (Holmberg, 2005). Hortaz, «irakaskuntza irekia» xede edo hezkuntza politika bat da, hots, era moldagarri batean irakastea, ikasle bakoitzaren muga geografiko, sozial eta denbora kontuan hartuta eraikita, ez irakaste instituzioarenak (Bates, 1999).

- «Urrutiko irakaskuntza» helburu hori lortzeko bidea da. Ikasleak material pedagogikoaren egilearengandik urrun egonda ikasteko era da, non haiek nahi duten lekutik eta irakaslearekin kontaktu pertsonal barik ematen den (Bates, 1999). Azken finean, termino horrek soilik bidalketa era zehazten du. Hortaz, «urrutiko hezkuntza» «hezkuntza irekia» izan daiteke, baina ez du zertan izan (Holmberg, 2005).

Internet erabileraren eta sareen zabalkuntzak, gailu elektronikoen demokratizazioarekin batera, «urrutiko hezkuntza» birtualtasunarako joera 
sustatu du, eta Internet konexioa eta ordenagailua ezinbesteko tresnak bihurtu urrutian ikasi ahal izateko.

Hezkuntza arloan «birtual» kontzeptuaren inguruko eztabaida dago; orokorrean, ordenagailu (edo bestelako gailu elektroniko) baten bidezko heziketarekin lotzen da. «Hezkuntza birtuala» definitzeko Martínez de Uribek Tintayak hurrengo definizio hau erabiltzen du: ikaskuntza-irakaskuntza prozesuaren modalitatea da, gizakia teknologia berriekin erlazionatzeko adimen-irudimenean oinarritzen dena, komunikazio sareen sorkuntzen bidez denbora mugarik gabe (Martínez, 2008). Horrekin batera, «gela birtuala» edo «e-gela» terminoaren erabilera zabaldu da, hezkuntza modalitate hori garatzeko toki birtuala izendatzeko. Orain arte, orokorrean, «gela birtual»-ak eduki-biltegi gisa erabili izan dira hots, edukiak transmititzeko ikuspuntu pedagogiko barik (Camacho, 2019). Horren harira, «e-» aurrizkia («e-learning», «e-education» eta abarren topa daitekeena) ingeleseko electronic hitzetik eratorritakoa da, elektroniko esan nahi duena. Ondorioz, «e-learning» bide elektronikoen bidezko ikaskuntza bezala definitzen da (Martínez, 2008), eta gauza bera beste terminoekin.

Interneten bidez garatutako hezkuntzan, hau da, online hezkuntzan, hiru ezaugarri nabarmentzen dira (Martínez, 2008). Lehenik, ikasleak bere denbora kudeatu behar du. Bigarrenik, ez dela toki zehatz batean gertatzen. Azkenik, elkarrekintza, hau da, ikaslearen eta irakaslearen arteko harremana ez da aurrez aurrekoa izaten.

Horretaz gain, ikasle eta irakaslearen arteko harremana irakaste prozesua gauzatzeko nolakoa izaten den kontuan hartuta, bitan sailkatzen da (Holmberg, 2005):

- Noranzko bakarreko bidea. Aldez aurretik irakaste antolatzaileak prestatutako kurtsoko materialak ikasleari bidaltzen zaizkio, baina ikasleak ez du irakasle edo tutore batekin elkar eragiteko aukerarik. Egoera hori zenbait unibertsitateetan gertatzen da, hala nola, Dutch Open Universiteit eta The Colombian Unisur unibertsitatetan.

- Bi noranzkoko bidea. Ikasleen eta irakaste antolatzailearen arteko komunikazio erreala egoten da. Instituzioak ikasle-irakasle arteko harremana bermatzen du, lehenari kurtsoan matrikulatzean bigarrenaren posta, telefonoa eta bestelako ordenagailuzko harreman jartzeko bideak eskainiz; esate baterako, British Open University-n.

Haatik, ikasle eta irakaslearen arteko harremana beste irizpideen arabera ere sailkatzen ohi da, hala nola denboraren arabera. Informazioa denbora errealean gertatzen denean komunikazio sinkronoa deitzen da (adibidez, bideodei batean parte hartzea). Informazioa denbora geroratuan trukatzen denean, ordea, komunikazio asinkronoa (adibidez, epe muga bat duen entregagaia) (Lamí, Pérez eta Rodríguez, 2016). Beraz, hezkuntza asinkronoan ikasleek euren denbora kudeatzeko malgutasuna dute, eta hezkuntza sinkronoan ordutegi zehatz bati jarraitzea beharrezkoa da. 
Aipatu beharra dago gaur egungo urrutiko hezkuntza ohikoena, hau da, online hezkuntza ingurune birtualean gauzatzen denez, ikaskuntza, komunikazioa eta ebaluazioa ere online izaten direla. Horrek online ikaslearen bakardadea, ikasleen baja kopuru handia edo ikasleek derrigorrean garatu beharreko gaitasunak eta trebeziak eragiten ohi ditu; beraz oso-osorik online hezkuntzaren efikazia zalantzatan jarri izan da (Camacho, 2019).

Irakaslearen eta ikaslearen aurrez aurreko harremanik gabeko hezkuntza hainbat ikerketatan aztertu da urteetan zehar, batez ere 1970eko hamarkadatik aurrera. Gaiarekin erlazionatuta aurkitutako lehen ikerketa 1906an idatzi zen, non posta bidezko nazioarteko heziketa eta izandako emaitzak aztertzen ziren (Clark, 1906).

Gaur egungo urrutiko hezkuntzaren jatorria postazko hezkuntzan kokatzen da, gehien bat helduei zuzenduta jaio izan zena (Holmberg, 2005). Aldez aurretik, heziketa helburua izanda urrutiko irakaskuntza zeukaten gutunak egonda ere (sumeriar, greko, erromatar... zibilizazioetan) (Holmberg, 1995) (García, 1999), ez dira orain urrutiko hezkuntzatzat joko litzatekeena. Frogatutako lehen posta bidezko irakaskuntza XVIII. mendean topatzen da, Battemberg-ek urrutiko hezkuntzaren arloan egindako ikerketan plazaratu zuena, 1720an Caleb Phillips The Boston Gazette egunkarian kaligrafia ikasteko posta bidezko eskolak eskaintzen zituen (Battemberg, 1971).

Bigarren Hezkuntzaren baliokide den hezkuntza mailetan urrutiko hezkuntzan izandako lehen urratsak 1910ean izan ziren. Victoriako Unibertsitateak (Australia) landa eremuko lehen mailetako irakasleek posta bidez bigarren mailako irakaskuntzarako formakuntza jasotzea bultzatu zuen. Urte gutxitara, 1914an, Unibertsitate horren Hezkuntza Sailak gertueneko ikasketa-zentrotik hamahiru kilmetrora bizi zen kolono baten gutuna jaso zuen, non ikastetxera egunero joateko ezintasunaren aurrean seme-alabak heziketa izateko laguntza eskatzen zuen. Egoera aztertu ostean, posta bidezko Lehen Hezkuntzako heziketa martxan hasi zen urrutiko landa eremuetan bizi izanda ere, hezkuntza ofiziala jaso ahal izateko, «posta bidezko gainbegiratutako ikasketak» deitu izan zena (García, 1999).

Era horretan, Australia izan zen era sistematikoan eta eskala handitan lehenengo eta bigarren mailetan posta bidezko hezkuntza (hau da, «urrutiko hezkuntza») erabili zuen lehen herrialdea (García, 1999). Teknologiak aurrera egin ahala, hezkuntza sistema egokitu zen irrati bidezko eskola elkarreragileak sortuz, horretan ere Australian aitzindariak izan ziren «Airearen Eskola»-ren sorkuntzarekin, gaur egun Internet bidezko komunikazioarekin osatzen dena. Espainian, Bigarren Hezkuntza ez-presentzial ofizialaren lehen proiektua 1962an abian jarritako Irrati-Batxilergoa izan zen, Centro Nacional de Enseñanza Media por Radio y Televisión-ek ordezkatu izan zuena (García, 1999), gaur egun CIDEADek ordezkatutakoa.

«Urrutiko hezkuntzaren» bilakaera kontuan hartuta, belaunalditan sailka daiteke, Lorenzo García Aretiok proposatutako sailkapena hezkun- 
tza ereduaren araberakoa da, denbora edo leku zehatza kontuan hartu gabe (García, 1999):

- 1. belaunaldia: posta bidezko hezkuntza. Ikasleak gaiak posta bidez jasotzen zituen, gehienetan ikasle eta irakaslearen arteko harreman elkarreragilerik gabe. XIX mendetik aurrera, tutorearen figura agertu zen, zuzenketak egiteko eta, noizean behin, bilera presentzialak egiteko... Gainera, telegrafoaren eta telefonoaren asmakuntza harreman horren eragile izan zen.

- 2. belaunaldia: telekomunikazio bidezko hezkuntza. Irratia eta telebistaren asmakuntzek urrutiko hezkuntzan eragin handia izan zuten, eta irratia, telebista, kasetteak eta telefonoa ezinbesteko tresnak bihurtu. Alabaina, belaunaldi horren kurtsoen diseinua ez dago ikasleen beharretara egokituta.

- 3. belaunaldia: hezkuntza telematikoa. 1980ko hamarkadatik aurrera Internet, sareen eta ordenagailuen zabalkundeak urrutiko hezkuntza bilakatzen du, ikaslearen antolakuntzari begira ikaskuntza programa malguak sortzea ahalbidetuz. Belaunaldi horren barruan, era «birtual»-ean garatutako ikaskuntza-irakaskuntza prozesuak azpiatal gisa egongo lirateke zenbait autoreren ustez (García, 1999). Beste batzuen ustez, ordea, laugarren belaunaldi bati dagokio (González eta Rodríguez, 2015).

Gaur egungo hezkuntza sistema aztertzen bada, COVID-19aren egoera alde batera utzita, Bigarren Hezkuntza urrutian egiteko aukera dago, estatu mailan Centro para la Innovación y Desarrollo de la Educación a Distancia-n (CIDEAD) eta EAEn Urrutiko Hezkuntzako Euskal Institutuan (UHEI) (hiru hiriburuetan egoitzapenak izanda), baina bakarrik hiru salbuspen betezen badira (Hezkuntza eta Lanbide Heziketa Ministerioa, d. g.):

- Atzerrian bizitzea espainiar nazionalitatea izanda.

- Atzerrian bizitzea, aldez aurretik espainiar ikasketa ofizialak hasi izanda.

- Espainian bizitzea, eta ezohizko arrazoiengatik (bizitza ibiltariko familia izatea edo aktibitate berezietan jardutea: dantza, musika, kirola...) ezin ikasi izatea ikasketa-zentroan. Kasu horietan, ikasleak Hezkuntza Administrazioaren ziurtagiria behar du. Horretaz gain, Batxilergoaren kasuan, ikaslearen komunitate autonomoan ikasi nahi izandako modalitatea ez egotea.

Ondorioz, Bigarren Hezkuntzan heziketa presentziala izatea derrigorrezkoa da, salbuespen bereziak izan ezik, bai DBHn, bai Batxilergoan. Horregatik, urrutiko modalitateko ikasleria gutxiengoa da. Hain ikasle gutxik ikasten dute DBH urrutian, ezen estadistikak egiterakoan gobernuak datu horiek deuseztatzen baititu. Hezkuntza eta Heziketa Profesionalaren 
Ministerioak hezkuntza estadiska atalan plazaratutako azken datu xehatuak kontuan hartuta (2019ko maiatzaren 29an), 2017/2018ko kurtsokoak, hurrengo grafiko hauek egin dira (ikusi 1. grafikoa eta 2. grafikoa).

Urrutiko hezkuntza

Hezkuntza presentziala

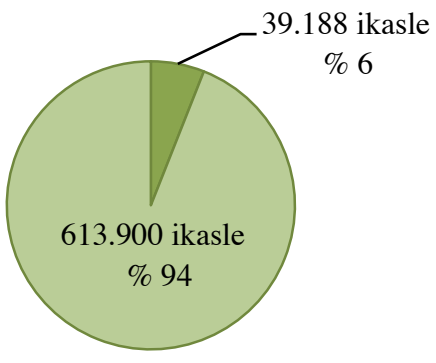

Iturria: Hezkuntza eta Lanbide Heziketa Ministerioa (2019). Estadísticas de la Educación, enseñanzas no universitarias: alumnado.

1. grafikoa

Bigarren Hezkuntza Espainian,

Batxilergoa 2017/2018 (Espainia)

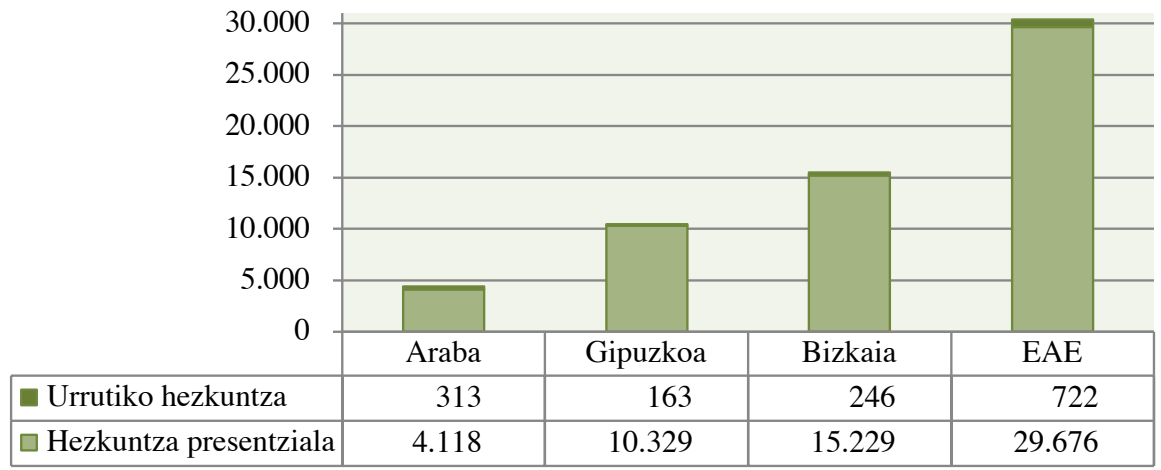

Iturria: Hezkuntza eta Lanbide Heziketa Ministerioa (2019). Estadísticas de la Educación, enseñanzas no universitarias: alumnado.

$$
\text { 2. grafikoa }
$$

Bigarren Hezkuntza EAEn, Batxilergoa 2017/2018 (EAE) 


\section{IKERKUNTZA-ARAZOA}

Ikerketa-lan honetako ikerkuntza-arazoan, jatorrizko hezkuntza presentziala izanda eta aldez aurretik urrutiko hezkuntzarekin kontakturik ez dela, bat-batean urrutiko hezkuntzara salto egin beharrak Bigarren Hezkuntzan izan duen eragina aztertzen da, hain zuzen ere, ikertzea aldaketa horrek zer suposatu duen ikasle eta irakasleentzat ikaste-irakaste prozesuan.

\section{METODOLOGIA}

\subsection{Hipotesi/galderen formulazioa eta justifikazioa}

Ikerkuntza-gaia zeharo berria denez, literaturan ez dago arloan jadanik egindako ikerketarik. Beraz, ezinezkoa izan da horietan oinarritutako hipotesi justifikatuak garatu ahal izatea. Hori dela eta, hipotesiak formulatu beharrean, galderak aurkeztuko dira. Aurreko ataleko ikerkuntza arazotik abiatuta, hiru adarretan banatutako galderak formulatu dira: egokitzapena, ikaskuntza eta irakaskuntza, eta ebaluazioa.

- Lehenengo adarra: egokitzapena:

- Irakasleak eta ikasleek urrutiko hezkuntzara egokitzeko prozesua bat-batean izatea hezkuntza kalitatean eragina izan du (irakasleen urrutiko hezkuntzan prestatzea, baliabideak, ikaslerik sistematik kanpo ez egotea bermatzea...)?

- Bigarren adarra: ikaskuntza eta irakaskuntza:

- Ikasleek urrutiko eskolak izatean, ikaste-erritmoa mantendu ahal izateko zailtasun handiagoak izan dituzte eta banakako lan gehiago egin behar dute?

- Bigarren hezkuntzako ikasleek urrutian ikasteko beharrezko autonomia eta denboraren kudeaketa egokia egiteko ardura dute?

- Bigarren Hezkuntzako ikasleek badute urrutian ikasteko beharrezko autonomia eta euren denbora kudeatzeko gaitasuna?

- Irakasleek urrutiko eskolak ematean, ikasleek euren ikaste-prozesuan aurrera egiten dutela ziurtatzeko oztopoak izaten dituzte eta lan gehiago egin behar dute?

- Aurrez aurreko komunikazioa ez egoteak ez du ikasleen zalantzak argitzea oztopatzen?

- Hirugarren adarra: ebaluazioa:

- Ebaluazioa egiteko orduan, urrutiko azterketetan ikasleek zintzo jokatzen dutela bermatzeko biderik badago?

- Azterketak ez diren beste ebaluazio erak erabili behar dira ikaslearen ikaste prozesua aurrera egin duela egiaztatzeko? 


\subsection{Hipotesi/galderen formulazioa eta justifikazioa}

- Lehenengo adarra:

- Irakasleen formakuntza urrutiko hezkuntzan:

-Definizio eratzailea (edo teorikoa): hezkuntza urrutian garatu ahal izateko irakasleek beharrezko formakuntza izatea, metodologia eta baliabideeen erabilerari dagokionez, kalitatezko hezkuntza bermatu ahal izateko.

-Definizio eragilea (edo operatiboa): ikastetxeak irakasleek formakuntza egokia jasotzen dutela ziurtatzea egoera berriari aurre egin ahal izateko, hezkuntza-kalitatea kaltetu barik, horretarako urrutian irakasteko metodologiak eta baliabide erabilgarriak ezagutaraziz. Horrez gain, jasotako formakuntza hori nolakoa izan den ere ezagutuko da.

- Irakasleak eta ikasleak beharrezko baliabideak izatea (Internet, ordenagailua, inprimagailua...)

-Definizio eratzailea (edo teorikoa): irakasleek eta ikasleek hezkuntza prozesua urrutian jarraitu ahal izateko beharrezko baliabideen edukitzearen bermea.

- Definizio eragilea (edo operatiboa): ikastetxeak irakasleek eta ikasleek beharrezko baliabideak dituztela ziurtatu ote duen, hots, Internet konexioa, ordenagailua, inprimatzailea..., eta gabeziez ohartzekotan nola konpondu duen.

- Gaitegia/metodologia urrutiko hezkuntzara egokitzea

- Definizio eratzailea (edo teorikoa): jatorrizko hezkuntza presentziala izanda urrutiko hezkuntzara aldatzean gaitegia edota metodologia egokitzearen beharra, hezkuntza-kalitatean eraginik ez izateko.

-Definizio eragilea (edo operatiboa): irakasgaiaren hezkuntzaprozesua aurrera eraman ahal izateko hezkuntza presentzialean erabilitako metodologia edota gaitegia moldatu behar izatea, zein ikasgaitan jakinda, baita nola ahalbidetu den egokitzapen hori.

\section{- Bigarren adarra:}

- Irakaskuntza:

-Definizio eratzailea (edo teorikoa): irakasteko ekintza eta horren ondorioa da (Harluxet, 2001). Beraz, ikasleek ezagutzak eta gaitasunak eskuratzea helburua duen ekintza da.

-Definizio eragilea (edo operatiboa): irakaskuntza prozesuan ezagutu ahal izateko ikasgaiaren helburuak betetzen diren, ikasleekiko atzeraelikadura bermatzen eta ikasleen ikasketa-prozesua egokia dela ziurtatzen jakin behar da. 
Gainera, irakasleen arteko koordinazioa ere garrantzi handikoa da.

- Ikaskuntza:

- Definizio eratzailea (edo teorikoa): ikasteko ekintza eta horren ondorioa, bereziki ezagutzak edo gaitasunak nork bere egiteko prozesua (K. Harluxet Fundazioa, 2001).

- Definizio eragilea (edo operatiboa): ikaskuntza prozesuaren garapenean eragina duten ezaugarriak aztertu behar dira. Horien artean ikasketa eta lan zama, denboraren kudeaketa, ikasleen autonomia eta ikaste-erritmoa mantentzeko banakako lana ezinbestekoak dira.

- Irakasle-ikasle komunikazioa:

- Definizio eratzailea (edo teorikoa): irakasleen eta ikasleen arteko harremana, baita euren artean gertatzen den truke, komunikazio edo elkarreragina (K. Harluxet Fundazioa, 2001).

- Definizio eragilea (edo operatiboa): urrutian egon arren, irakasleen eta ikasleen arteko komunizaioa dagoela ziurtatzea, hori gauzatzeko bidea ezagututa, baita erantzunak emateko denbora ere.

- Arazo teknikoak:

- Definizio eratzailea (edo teorikoa): gailuekin edo beste baliabide teknikoei dagokionez askabide edo erantzuna eskatzen duen gaia; erabakitzeko edo konpontzeko edozein eratako eragozpenak agertzen dituen egitekoa (K. Harluxet Fundazioa, 2001).

- Definizio eragilea (edo operatiboa): irakasle eta ikasleek erabilitako gailu eta baliabide teknikoekin arazoak izatekotan, hots, ordenagailua, mikrofonoa, kamera, Internet konexioa, inprimagailuarekin... irakaskunta/ikaskuntza prozesuan izandako eragina, eta arazoak daudenean konponbidea topatzea, hezkuntzakalitatea ez kaltetzeko.

- Etxeko giroa

- Definizio eratzailea (edo teorikoa): etxean hautematen diren eta pertsonarengan eragina izaten duten inguru-baldintzen multzoa, bertako jarduera, pertsonen jarrera eta bestelako ezaugarriek baldintzatua (K. Harluxet Fundazioa, 2001).

-Definizio eragilea (edo operatiboa): ikaste eta irakaste tokian dagoen giroaren egokitasuna hezkuntzaren kalitatea bermatzeko, hau da, ikasleen eta irakasleen etxeetan. Beraz, kontuan izan beharko dira eteteak eta distrazioak izatea edo ez izatea. 


\section{- Hirugarren adarra:}

- Ebaluazioa:

- Definizio eratzailea (edo teorikoa): ebaluatzeko ekintza eta horren ondorioa (Harluxet, 2001), hau da, ikasleen ezagutza, gaitasunak eta errendimendua balioztatzea (RAE, 2019).

-Definizio eragilea (edo operatiboa): ikasleen ezagutza, gaitasunak eta errendimendua urrutian balioztatu ahal izateko, hau da, ebaluatu ahal izateko erabiltzen diren tresnak.

\subsection{Diseinua}

Ikerketa honetan jarraitu den diseinua ez-esperimentala da, hain zuzen ere, diseinu ex-post-facto deskriptibo korrelazionala. Izan ere, ikerketa honetan aztertu nahi dira bat-batean urrutiko hezkuntzara salto egin beharrak Bigarren Hezkuntzan zer suposatu duen ikasle eta irakasleentzat ikaste-irakaste prozesuan, eta aurreko ataletan azaldutako aldagaiekin dituzten erlazioak.

Bere izenak adierazten duen bezala, ex-post-facto diseinuetan jadanik gertatutako egoera bat aztertzen da. Kasu honetan, urrutiko hezkuntzara bat-bateko aldaketa eta ostean izandako egoera.

Aipatu beharra dago ikerketa deskriptiboak ez direla datuen bilketa hutsa egoera bat azalarazteko. Horien xedea hezkuntzaren gaurkotasuneko arazo eta egoerekin lotura duten galderei erantzuna ematea da, hau da, hezkuntza kalitatean izandako eragina urrutiko hezkuntzara bat-batean aldatzea Bigarren Hezkuntzan.

Ikerketa korrelazionalean ez da esku-hartzerik egiten errealitatean. Ikerketa honen helburua gertakizun edo egoera batean parte hartzen duten aldagaien arteko erlazio aztertzea da, eta beraz, ez da aldagaien manipulaziorik egiten, behaketa baizik. Horretarako, datuen bilketa gauzatu ostean estadistikoki kalkulatzen da aldagaien arteko korrelazioa (Bisquerra, 2009).

Aipatutako aldagaiak honako hauek dira: egokitzapena (formakuntza, baliabideak eta gaitegia/metodologia), irakaskuntza-ikaskuntza (iraskaskuntza prozesua, ikaskuntza prozesua, irakaslearen eta ikasleen arteko harremana, arazo teknikoak eta etxeko giroa) eta ebaluazioa (ebaluatzeko tresnak). Ikerketa honetan, ezin izango dira aldagai horiek manipulatu. Horrenbestez, ikerketa aurrera eramateko, hiru frogaren bidezko azterlan bat egin da: ikasleen galdetegia, irakasleen galdetegia eta elkarrizketak irakasleekin. Alde batetik, hezkuntza kalitatean aldagai horiek izandako eragina neurtzeko bi galdetegi erabiliko dira, bat ikasleentzat eta bestea irakasleentzat. Bestetik, egoeraren ezagutza izanda, gehiago sakondu ahal izateko, irakasleekin egindako elkarrizketa erdi-egituratuak erabiliko dira. 
Ikus daitekeenez, lortuko diren emaitzak kuantitatiboak eta kualitatiboak izango dira; beraz, oinarrizko estrategia bezala konbinazioa erabiliko da, eta datu kualitatiboek kuantitatiboak osatuko dituzte. Ikerketa konbinazionala da, lehenengo neurketa kuantitatibo bat egin delako (ikasle eta irakasleentzako galdetegien bidez) eta, galdetegietan lortutako emaitzen analisia egin ondoren, irakasleekin elkarrizketak antolatu direlako, ikasleen ikaste prozesuaz eta garapenaz informazioa biltzeko, baita urrutiko hezkuntzaren arloan ikusten duten onurez edota gabeziez informazio gehigarria jasotzeko.

\subsection{Laginketa}

Ikerketa honetan populazioa Euskal Autonomia Erkidegoko (EAE) Bigarren Hezkuntzako ikasle-irakasle guztiek osatzen dute (DBHko lehen mailatik Batxilergoko bigarren mailara arte) eta laginketa unitatea ikasletaldeak dira (konglomeratua).

Ikastetxeak aukeratzeko, ikerketa proiektu honetan parte hartzeko prest dauden irakasleen araberako iritzizko ez ausazko laginketa egin da. Guztira hogeitabost ikasketa-zentrok osatzen dute lagina, hain zuzen ere 1. taulan jasotzen direnak.

1. taula

Ez-ausazko laginketa

\begin{tabular}{|c|c|c|c|c|c|}
\hline & Ikasketa-zentroa & Eredua & Mailak & Ikasleak & Irakasleak \\
\hline \multirow{3}{*}{ Araba } & $\begin{array}{l}\text { Helduentzako institutu publikoa } \\
\text { (Gasteiz) }\end{array}$ & A, D & DBH 4 & 0 & 1 \\
\hline & Itunpeko kristau eskola (Gasteiz) & - & DBH 2-4 & 0 & 1 \\
\hline & Institutu publikoa (Laudio) & $\mathrm{D}$ & $\begin{array}{l}\text { DBH } 1,2,4 \\
\text { Batx. } 2\end{array}$ & 0 & 5 \\
\hline \multirow{5}{*}{ Bizkaia } & $\begin{array}{l}\text { Itunpeko ikastola (Amorebieta- } \\
\text { Etxano) }\end{array}$ & $\mathrm{D}$ & Batx. 1 & 1 & 0 \\
\hline & $\begin{array}{l}\text { Institutu publikoa (Amorebieta- } \\
\text { Etxano) }\end{array}$ & $\mathrm{D}$ & $\begin{array}{l}\text { DBH } 3,4 \\
\text { Batx. } 1,2\end{array}$ & 0 & 1 \\
\hline & Itunpeko kristau eskola (Barakaldo) & B & DBH 2 & 1 & 0 \\
\hline & Itunpeko kristau eskola (Barakaldo) & A, B & $\begin{array}{l}\text { DBH 1-4 } \\
\text { Batx. } 1,2\end{array}$ & 57 & 10 \\
\hline & Institutu publikoa (Barakaldo) & $A, B, D$ & DBH 4 & 8 & 7 \\
\hline
\end{tabular}


Ainhize Gamarra

\begin{tabular}{|c|c|c|c|c|c|}
\hline & Ikasketa-zentroa & Eredua & Mailak & Ikasleak & Irakasleak \\
\hline \multirow{13}{*}{$\begin{array}{l}\text { Bizkaia } \\
\text { (jarraitu) }\end{array}$} & Institutu publikoa (Barakaldo) & $\mathrm{D}$ & $\begin{array}{l}\text { DBH } 3 \\
\text { Batx. 1,2 }\end{array}$ & 31 & 3 \\
\hline & Institutu publikoa (Barakaldo) & $\mathrm{B}, \mathrm{D}$ & $\begin{array}{l}\text { DBH 3,4 } \\
\text { Batx. } 1\end{array}$ & 0 & 2 \\
\hline & Itunpeko ikastetxea (Bilbao) & - & DBH $1,3,4$ & 0 & 1 \\
\hline & Itunpeko kristau eskola (Bilbao) & $\mathrm{A}, \mathrm{B}, \mathrm{D}$ & $\begin{array}{l}\text { DBH } 3 \\
\text { Batx. 1,2 }\end{array}$ & 0 & 1 \\
\hline & Itunpeko kristau eskola (Bilbao) & $\mathrm{B}, \mathrm{D}$ & Batx. 1 & 10 & 0 \\
\hline & Institutu publikoa (Bilbao) & $\mathrm{A}, \mathrm{B}, \mathrm{D}$ & DBH 1,2 & 1 & 0 \\
\hline & Institutu publikoa (Erandio) & $\mathrm{B}, \mathrm{D}$ & DBH 2-4 & 0 & 1 \\
\hline & Itunpeko kristau eskola (Lauroeta) & A & $\begin{array}{l}\text { DBH } 4 \\
\text { Batx. 1,2 }\end{array}$ & 0 & 1 \\
\hline & Itunpeko kristau eskola (Leioa) & $\mathrm{D}$ & DBH 3 & 78 & 2 \\
\hline & Itunpeko ikastola (Ortuella) & $\mathrm{D}$ & DBH 1-3 & 0 & 1 \\
\hline & Itunpeko ikastola (Portugalete) & $\mathrm{D}$ & DBH 1-4 & 0 & 1 \\
\hline & Institutu publikoa (Sestao) & - & DBH 2 & 0 & 1 \\
\hline & Itunpeko ikastetxea (Sodupe) & $\mathrm{D}$ & $\begin{array}{l}\text { DBH 1,2 } \\
\text { Batx. 1,2 }\end{array}$ & 0 & 2 \\
\hline \multirow{4}{*}{ Gipuzkoa } & Institutu publikoa (Elgoibar) & $\mathrm{D}$ & Batx. 2 & 7 & 0 \\
\hline & Itunpeko kristau eskola (Donostia) & $\mathrm{D}$ & $\begin{array}{l}\text { DBH } 2 \\
\text { Batx. } 1\end{array}$ & 10 & 0 \\
\hline & Institutu publikoa (Donostia) & $\mathrm{A}, \mathrm{B}, \mathrm{D}$ & DBH 2 & 1 & 0 \\
\hline & Urrutiko institutu publikoa (Donostia) & $\mathrm{A}, \mathrm{B}, \mathrm{D}$ & DBH 1-4 & 0 & 1 \\
\hline Guztira & 25 ikasketa-zentro & $\mathrm{A}, \mathrm{B}, \mathrm{D}$ & $\begin{array}{l}\text { DBH 1-4 } \\
\text { Batx. 1,2 }\end{array}$ & 205 & 42 \\
\hline
\end{tabular}

\subsection{Datuak biltzeko tresnen deskribapena}

Ikerketa hau gauzatu ahal izateko, aldagaien definizioen atalean adierazitako aldagaiei buruzko informazioa bildu behar izan da. Horretarako, neurrira diseinatutako tresnak erabili dira: ikasle-galdetegia, irakasle-galdetegia eta irakasleekiko elkarrizketak. 
Behin datu kuantitatiboak bilduta (galdetegien bidez), datu kualitatiboak bildu dira (elkarrizketen bidez) lehenengoetan lortutako informazioan sakontzeko. Era horretan, galdetegien eta elkarrizketen bitartez bildutako datuak triangelatzeko aukera egon da, bi metodoei esker lortutako datuen ondorioak konbinatuz.

\subsubsection{Galdetegiak}

Tresna honen bidez, datuak biltzeko neurgailu objetiboa dena, ikasle eta irakasle bakoitzari galdetu zaio urrutiko hezkuntzarako aldaketak bere ikaste/irakaste prozesuan eta hezkuntza-kalitatean orokorrean izandako eraginaz. Horretarako, bi galdetegi ezberdin prestatu dira ${ }^{1}$ (bakoitza hogeitasei galderez osatuta). Lehenengoa, ikasleen ikuspuntutik aztertu ahal izateko eta, bigarrena, irakasleenatik. Ikasle- eta irakasle-galdetegiak prestatzeko beste egile batzuek egindako galdetegi estandarrak oinarritzat hartu dira (Martín, 2013) (Réparaz-Abaitua, 2004) (Santoveña, 2010), eta ikerkuntza-arazo hau aztertzeko egokitu. Antolaketari dagokionez, galdetegien itemak dimentsioetan banandu izan dira, hurrengo taula honetan erakusten direnak.

2. taula

Galdetegien dimentsioak

\begin{tabular}{|c|c|c|}
\hline Dimentsioa & Galdetegia & Itema \\
\hline \multirow{2}{*}{ I. Urrutiko hezkuntzarekiko aurreko kontaktua } & Irakasleak & $1,2,3$ \\
\hline & Ikasleak & 1,2 \\
\hline \multirow{2}{*}{ II. Baliabideak: plataformaren erabilera } & Irakasleak & 4,5 \\
\hline & Ikasleak & $3,4,5,6$ \\
\hline \multirow{2}{*}{ III. Baliabideak: gailu eta arazo teknikoak } & Irakasleak & $6,7,8,9$ \\
\hline & Ikasleak & $7,8,9$ \\
\hline \multirow{2}{*}{ IV. Ikaskuntza eta irakaskuntza } & Irakasleak & $\begin{array}{l}10,11,12,13,14,15,16,17 \\
18,19,20,21,22,23,24,25,26\end{array}$ \\
\hline & Ikasleak & $\begin{array}{l}10,11,12,13,14,15,16,17 \\
18,19,20,21\end{array}$ \\
\hline V. Irakasleria & Ikasleak & $22,23,24,25,26$ \\
\hline
\end{tabular}

${ }^{1}$ Erabilitako galdetegiak hurrengo esteketan topa daitezke:

- Irakasleentzako galdetegia: https://forms.gle/MWe8oPd2r481qM217

- Ikasleentzako galdetegia: https://forms.gle/ufXpErDNPS2YVLA18 
Ikasleen kasuan, hezkuntza kalitatean izandako eragina aztertu ahal izateko, galdetegiak biltzen dituen galderek hurrengo ordena honi jarraitzen diote: aurreko kontaktua urrutiko hezkuntzarekin, erabilitako baliabideak (plataforma, gailuak...), horiekin izandako arazo teknikoak, ikaskuntza prozesua eta irakasleriarekiko harremana eta kontaktua.

Irakasleen kasuari dagokionez, galderen ordena hau izan da: aurreko kontaktua urrutiko hezkuntzarekin, formakuntza, erabilitako baliabideak (plataforma, gailuak...), horiekin izandako arazo teknikoak, irakaskuntza prozesua (ebaluazioa barne) eta ikasleriarekiko eta beste irakasleekiko harremana eta kontaktua.

Nahiz eta galdera gehienak itxiak izan, galdetegi bakoitzean galdera ireki bat gehitu da, informazio gehigarria izatekotan bete dezaten. Galdera itxien eskalei dagokienez, egoera baten atsegintasun maila ezagutzeko, Likert eskalaren bidez galdetu da. Egoera baten baiezko edo ezezko erantzuna lortzeko, ordea, bai/ez itemak erabili dira.

Bi galdetegiak irakasleei e-mailez bidali zaizkie, hau da, ikasleena eta irakaslearena. Galdetegiak Google Formulario tresnaren bidez sortu direnez, bete bezain laster jaso dira, batzeko arduraduna behar barik. COVID-19ari aurre egiteko etxean konfinatuta egon beharra dela eta, ezinezkoa izan da aurrez aurre ikasleei galdetegiak ematea momentu zehatz batean, eta ikasleei galdetegia betetzera behartu. Ondorioz, aurrez-aurre egin balitz baino erantzun-tasa baxuagoa espero zen.

\subsubsection{Elkarrizketak}

Horrez gain, irakasleekiko elkarrizketak egin dira. Era horretan, analisi kualitatiboa aurreko fasean egindako analisi kuantitatiboko emaitzetan oinarrituta garatu da eta, kasu partikular batzuetan, sakontzea ahalbidetu du. Analisi kualitatiboa egiteko «analisi ulerkorra» erabili da. Era horretan, kategoria batzuk baztertu dira, informazio guztia kodifikatu da eta, ostean, kategoria bakoitzaren deskribapena eta interpretazioa egin da. Analisi horren garapenean agertu den arazoa da, informazioa zenbakiz adierazita ez dagoenez, ezin dela estatistikoki tratatu (Lukas eta Santiago, 2016).

Elkarrizketako informazio egokiena eskuratu ahal izateko, elkarrizketak erdi-egituratuak izan dira (erabiltako gidoia, 3. taulan). Irakasleek adierazitako informazioa aztertu ahal izateko grabatu eta transkribatu egin dira. Gauzatzeko bideari dagokionez, aurrez aurre egitearen ezintasuna dela eta, telefonoz edo bideodeiaz egin dira. Horretarako, aldez aurretik irakasle bakoitzarekin adostu da bidea eta data. 
3. taula

Elkarrizketa erdi-egiturauetan jarraitu den gidoia

\begin{tabular}{|c|c|}
\hline \multicolumn{2}{|c|}{ Elkarrizketa erdi-egituratuen gidoia } \\
\hline \multirow[t]{3}{*}{$\begin{array}{l}\text { 1. Urrutiko hezkuntzarekiko } \\
\text { aurreko kontaktua }\end{array}$} & $\begin{array}{l}\text { Zer motatako formakuntza jaso da? [Kurtsoak, ba- } \\
\text { liabideak ezagutaraztea, saio bat...] }\end{array}$ \\
\hline & Egoera hau baino lehen formakuntzarik bazenuen? \\
\hline & $\begin{array}{l}\text { Jasotako formakuntza nahikoa izan da? Egoera } \\
\text { honi aurre egiteko prest zaudela uste duzu? }\end{array}$ \\
\hline \multirow{2}{*}{$\begin{array}{l}\text { 2. Ikasketa-zentroak eman- } \\
\text { dako baliabideak }\end{array}$} & Ordenagailua eta Internet konexioa ikasleei \\
\hline & Ordenagailua eta internet konexioa irakasleei \\
\hline 3. Egokitze-prozesua & Zailtasun nagusiak \\
\hline 4. Eskola-orduak & $\begin{array}{l}\text { Hezkuntza presentzialeko ordutegia mantendu da } \\
\text { ala murriztu da? Zergatik? }\end{array}$ \\
\hline \multirow[t]{3}{*}{ 5. Irakaste-prozesua } & Komunikazioa ikasleekin eta euren familiarekin \\
\hline & Ikasleriaren autonomia \\
\hline & Atzeraelikadura \\
\hline \multirow[t]{2}{*}{ 6. Ebaluazioa } & Ebaluazio tresnak eta irizpideak \\
\hline & Zailtasun nagusiak eta konponbideak \\
\hline
\end{tabular}

\subsection{Prozedura}

Ikerketa hau egiteko, hurrengo urrats hauek jarraitu dira:

1. Ikastetxeen aukeraketa. Euskal Autonomia Erkidegoko (EAE) zenbait ikastetxe hautatu dira, ikerketa-proiektu honetan parte hartzeko prest dauden irakasleen araberako ez-ausazko laginketa eginez; guztira hogeitabost ikasketa-zentro.

2. Ikastetxeekin harremanetan jartzea eta baimenak lortzea. Aukeratu diren ikastetxeekin harremanetan jartzea, ikastetxeko zuzendari eta irakasleei baimena eskatzeko. Oniritzirik ez lortzekotan, ordezkoak bilatzera jo beharko zen. Berriz, baimena lortzekotan, haiei ikerketaren nondik norakoak ondo azalduko litzaizkie. Azkenik, ikastetxe bakoitzarekin galdetegiak bidaltzeko eta jasotzeko datak zehaztuko dira.

3. Laginen aukeraketa. Iritzizko ez-ausako lagina hautatu da. Horretarako, ikerketa honetan parte hartzeko prest dauden irakasleek proposatutako ikasle-taldeak aukeratu dira, DBHko lehen mailatik Batxilergoko bigarren mailara arte.

4. Aldagaiak neurtzeko galdetegiak prestatzea. Ikerketan honetan erabili diren galdetegiak prestatu dira, ikasleentzako eta irakasleentzako galderak zehaztuz, aurreko atalean azaldu den bezala. 
Galdetegiak urrutitik errazago bete eta bildu ahal izateko Google Formulario tresna erabili da haiek sortu eta zabaltzeko.

5. Galdetegiak pasatzea ikastetxeetan. Irakasleei bete beharreko bi galdetegien estekak bidali zaizkie e-mailen bidez, hau da, ikasleena eta irakasleena. Irakasle bakoitzak erabaki du bere ikasleei dagokien galdetegia emateko bidea. Horren bidez, ikerkuntza arazoaren neurketa kuantitatibo bat egitea ahalbidetuko da.

6. Galdetegiak batzea. Google Formulario-ren ezaugarriei esker, galdetegiak bete ostean «bidali» botoia sakatzean datuak zuzenean biltzen dira. Beraz, galdetegiak batzeko arduradunik ez da beharrezkoa izan.

7. Datuen tratamendua. Ikasleen eta irakasleen galdetegietatik jasotako datu guztiak bildu, ordenagailura pasatu, antolatu eta analizatu dira, aztertu nahi diren aldagaiekin korrelazioak bilatuz. Horretarako tresna estatistikoak erabili dira.

8. Irakasleekin egin diren elkarrizketak prestatzea. Irakasleekin egin diren elkarrizketetatik informazio egokiena eskuratu ahal izateko, erdi-egituratutak egin dira. Analisi kualitatibo hori aurreko fasean egindako analisi kuantitatiboko emaitzetan oinarrituta egon da eta kasu partikular batzuetan sakontzea ahalbidetu du.

9. Irakasleekiko elkarrizketak egitea. Irakasleekiko elkarrizketak egin dira ikasleen ikaste-prozesuaz eta garapenaz informazioa biltzeko, baita urrutiko hezkuntzaren arloan ikusten duten onurez edota gabeziez hitz egiteko.

10. Ondorioak ateratzea. Lortutako emaitzak sakonki aztertu dira eta horietatik ondorioak atera dira. Ikerkuntza-arazoan planteatutako arazoa, baita hipotesi/galderei erantzuna eman daitekeen aztertu da.

11. Artikulua idaztea. Ikerketaren testuingurua, helburua, hipotesiak, metodologia, emaitzak, ondorioak eta bestelako alderdiak azaltzen dituen artikulua erredaktatu da.

\section{EMAITZEN AZTERKETA}

Galdetegietan lortutako emaitzak aztertu dira, ikasleen eta irakasleen erantzunak analizatuz eta interpretatuz. Hala ere, bi galdetegien item guztiak aztertzea gehiegizkoa denez, atal honetan esanguratsuenak bakarrik azalduko dira.

Erantzunak aztertu ostean, Likert eskalan erabilitako itemetan batezbestekoa eta desbideratze tipikoa kalkulatu dira, hurrengo tauletan aurkitzen direnak (4. taulan irakasleen galdetegiari dagozkionak eta 5. taulan ikasleenak $^{2}$ ). Horretaz gain, Guttman eskalako itemak, hots, bai al ez erantzunekoak, portzentajeen bidez adierazi dira.

\footnotetext{
${ }^{2}$ Datuen adierazpenei dagokienez, hemendik aurrera galdetegien tauletan eta grafikoen alboko tauletan bi galdetegien itemak ezberdintzeko, itemen zutabean irakasleen kasuan «Ir.» agertuko da zenbakia baino lehen, eta ikasleen kasuan, «Ik.».
} 
4. taula

Irakasleen galdetegiaren Likert eskalako itemak

\begin{tabular}{c|ccc}
\hline Dimentsioa & Itema & Batezbestekoa & Desbideratze tipikoa \\
\hline \multirow{2}{*}{ II } & Ir. 4 & 3,77 & 0,97 \\
& Ir. 5 & 3,98 & 0,74 \\
\hline \multirow{3}{*}{ III } & Ir. 6 & 2,40 & 0,90 \\
& Ir. 7 & 3,12 & 0,96 \\
\hline \multirow{5}{*}{ IV } & Ir. 10 & 3,33 & 0,83 \\
& Ir. 11 & 1,53 & 0,66 \\
& Ir. 12 & 3,00 & 1,02 \\
& Ir. 14 & 3,33 & 0,99 \\
& Ir. 15 & 3,60 & 1,09 \\
& Ir. 16 & 3,47 & 0,88 \\
& Ir. 17 & 2,93 & 0,77 \\
& Ir. 18 & 4,02 & 1,08 \\
& Ir. 19 & 3,63 & 1,02 \\
& Ir. 20 & 3,79 & 1,06 \\
& Ir. 21 & 3,49 & 1,03 \\
& Ir. 22 & 2,23 & 0,75 \\
& Ir. 23 & 2,86 & 0,80 \\
& Ir. 24 & 3,51 & 1,58 \\
& Ir. 26 & 2,09 & 0,65 \\
\hline
\end{tabular}

5. taula

Ikasleen galdetegiaren Likert eskalako itemak

\begin{tabular}{c|ccc}
\hline Dimentsioa & Itema & Batezbestekoa & Desbideratze tipikoa \\
\hline \multirow{6}{*}{ II } & Ik. 3 & 3,56 & 1,01 \\
& Ik. 4 & 2,87 & 1,02 \\
& Ik. 5 & 3,85 & 0,92 \\
& Ik. 6 & 3,55 & 0,84 \\
& Ik. 8 & 2,67 & 1,05 \\
\hline \multirow{6}{*}{ IV } & Ik. 10 & 3,55 & 0,97 \\
& Ik. 13 & 2,91 & 1,63 \\
& Ik. 14 & 2,17 & 0,89 \\
& Ik. 15 & 1,79 & 0,80 \\
& Ik. 16 & 3,17 & 0,98 \\
& Ik. 17 & 2,30 & 0,95 \\
& Ik. 18 & 2,59 & 1,00 \\
& Ik. 19 & 3,22 & 0,89 \\
& Ik. 20 & 3,01 & 0,94 \\
& Ik. 21 & 2,35 & 0,94 \\
\hline \multirow{6}{*}{ V } & Ik. 22 & 2,60 & 0,98 \\
& Ik. 25 & 2,15 & 0,92 \\
& Ik. 26 & 3,49 & 0,92 \\
\hline
\end{tabular}




\subsection{Urrutiko hezkuntzarekiko aurreko kontaktua}

Urrutiko hezkuntzarekiko aurreko kontaktuari dagokionez, galdetu da aldez aurretik ikasi duten (irakasle-galdetegia: 1. itema; ikasle-galdetegia 1. itema), baita irakatsi ere irakasleen kasuan (irakasle-galdetegia: 2. itema). Ikus daitekeenez, ikasleen \% 2k soilik izan du aldez aurretik eskolak urrutitik (atzerritar hizkuntzetakoak edo eskola partikularrak, ez Lehen Hezkuntzako edo Bigarren Hezkuntzako heziketarik). Irakasle gehienek, aldiz, ikasi dute urrutian (batez ere masterrak edo formakuntza osagarriko kurtsoak). Dena den, irakasleen \% 93k ez du inoiz urrutian irakatsi.

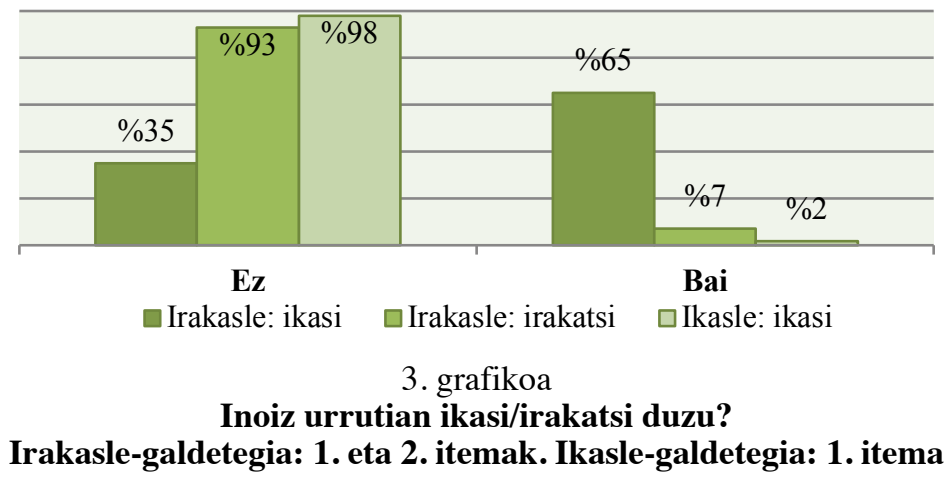

Urrutian ikasteak ezinbesteko bihurtzen du plataforma baten erabilera. Horregatik, oraingo egoera baino lehen plataforma bat erabiltzen ote zuten aztertu nahi izan da (ikasle-galdetegia: 2. itema), baina ia ikasleriaren laurdenak adierazi du ez zuela aldez aurretik plataforma bat erabili, eta irakasgai gehienetan bat-batean sortu behar izan zen, ez zutelako erabiltzen.

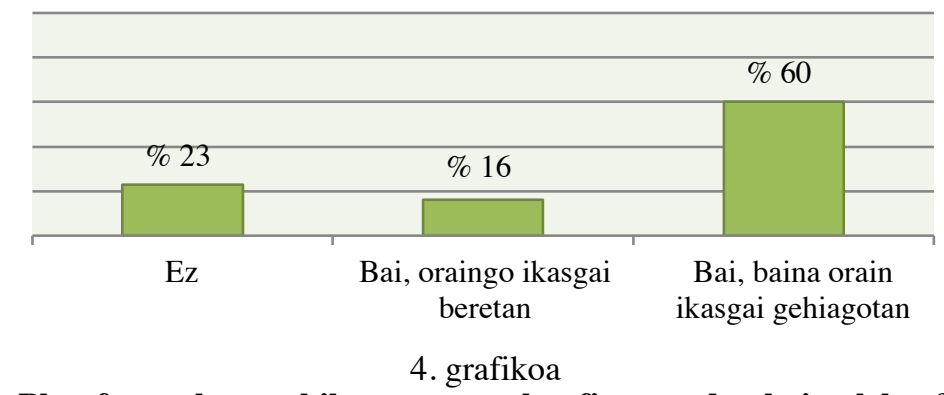

Plataforma bat erabiltzen zenuen konfinamendua baino lehen? Ikasle-galdetegia: 2. itema 
Irakasleen prestakuntzari buruz galdetzean (irakasleen galdetegia: 3. itema), \% 65ek ikasketxeak formakuntza eskaini diela dio. Hala eta guztiz ere, hezkuntza semipresentzialean lan egiten dutenek soilik izan dute kurtso osoan zehar prestakuntzarik. Beste ikasketa-zentroetako irakasleriak ikasketxeak bertan behera geratu ostean izan dute baliabideak ezagutarazteko, bideo tutorialak helarazteko... formakuntza saio bat.

Elkarrizketetan azaltzen den bezala, beste kurtsoetan zehar IKT eta komunikazio digitalekin lotutako baliabideak ezagutarazteko saioak izan arren, ez dute urrutian irakasteko prestakuntza berezirik jaso. Halere, ikasketa-zentroak itxi ostean ikastetxeak mezu elektronikoen bitartez zenbait baliabide interesgarri aurkeztu dizkie. Egia esan, irakasleek nabarmentzen dute euren jakinmina eta aldez aurretik ezagutzak izatearen garrantzia. Hori dela eta, euren ezagutzak eta jasotako baliabideak kontuan hartuta urrutian irakasteko moldatzen direla diote. Inferentzia baxuko ebidentziak ${ }^{3}$ sartu dira arestian esandakoa indartzeko:

«Más que con lo que hemos recibido, pues también con los conocimientos previos que yo tenía sí considero que, bueno, que me puedo defender» (1. elkarrizketa)

«Lo que he aprendido ahora, por ejemplo, por mi cuenta y con otros compañeros sobre la marcha o así, ha sido, por ejemplo, a hacer videollamadas con los chavales, y luego pues, por ejemplo, lanzar los exámenes y las correcciones y demás.» (2. elkarrizketa).

\subsection{Baliabideak: plataformaren erabilera}

Orokorrean, plataformaren erabilerari dagokionez, bai irakasleentzat, bai ikasleentzat erraza edo arrunta izateaz gain, funtzionamendua ona izan da. Beraz, arazorik ez denez egon, gaia jorratu ahal izateko egindako galderen grafikoak ez dira artikulu honetan txertatu, esanguratsuak ez direlako.

\subsection{Baliabideak: gailu eta arazo teknikoak}

Oro har, ikastetxe gehienek ikasleak urrutiko hezkuntza jarraitu ahal izateko ordenagailuak edo tabletak izatea bermatu dute, baina Internet konexioari dagokionez oso ikasketa-zentro gutxik hartu dute parte. Haatik, ia ikasleen erdiak adierazi du ikastetxeak baliabideak izatea ez duela ziurtatu

${ }^{3}$ Elkarrizketak gazteleraz egin zirenez inferentzia baxuko ebidentziak (edo lekukoak) bere hizkuntzan mantentzea erabaki da ñabardurak gal ez daitezen. 
(ikasle-galdetegia: 9. itema). Irakasleen galdetegietan, aldiz, azaltzen dute nola ikasleen egoeraz jabetzeko ahaleginak pribatuki egin diren, behar duten ikasleei ordenagailua edo tabletak helarazteko (irakasleen galdetegia: 8. eta 9. itemak).

Ikasleen eta irakasleen informazioek kontraesankorrak ziruditenez, elkarrizketetan gaian sakondu nahi izan da. Horietan jakin izan den bezala, institutu publikoetan «Eskola 2.0» proiektua (ikasgela barruan ikasle bakoitzak ordenagailu eramangarri bat izatea bermatzen duena) martxan zegoen. Egoera hasieran pentsatzen zutena baino gehiago luzatzen ari zenez, Eusko Jaurlaritzaren aginduz, behar duten ikasleei ordenagailu bat helarazi zaie, hots, ikastetxean bertan erabiltzen zuena (itunpeko ikastetxeetan ere antzeko proiektuak daude, eta horietan ere ziurtatu egin dira baliabideak). Horrez gain, Internet konexioa bermatu denean, ikasketa-zentroak antolatu eta ordaindu izan du, orokorrean, USB pintxo-modemen bidez (beste batzuetan, erakunderen batek laguntza gisa eskaini du). Irakasleei dagokienez, hezkuntza publikoan lan egiten dutenei ordenagailu eramangarria eskaini zaie, baita Internet konexioa ere. Baliabideekin lotutako hurrengo inferentzia baxuko ebidentziak gehitzen dira aipatutakoa indartzeko:

«Se ha asegurado a través de los tutores que hemos ido viendo a ver si tenían algún problema llamando a casa y los que no tenían, pues a través de los ordenadores Eskola 2.0; y para proporcionar Internet, pues no sé si a través de pinchos o qué sistema había también» (1. elkarrizketa)

«Sé que ha sido el instituto, mi instituto, el que pagando de su bolsillo ha comprado modems, de estos pinchos USB.» (2. elkarrizketa)

Internet konexioaren harira, 5. grafikoan ikusten denez, ikasleriaren laurden batenak lan abiadura arazoak sortarazi ditu, denbora asko eman baitu kargatzeko eta eskolak jarraitzea zaildu baitu (ikasleen galdetegia: 7. itema).

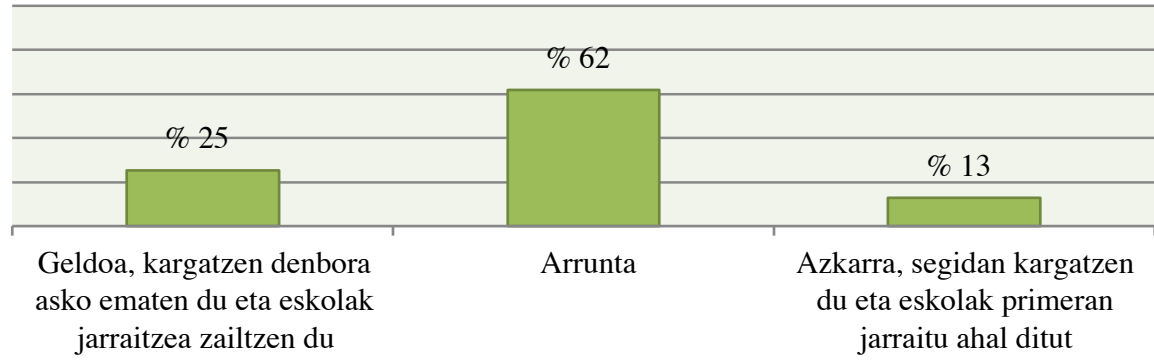

5. grafikoa

Lan abiadura (Internet konexioa) eskolak (bideodeia) jarraitzeko Ikasle-galdetegia: 7. itema 
Arazo teknikoei dagokienez (irakasle-galdetegia: 6. eta 7. itemak; ikasle-galdetegia: 8. itema), 6. grafikoan ikus daitekeen bezala, irakasleen baliabideek eragindakoak ez dituzte eskolak oztopatu, eta izandakoak momentuan konpondu ahal izan dira gehienetan. Ikasleen arazoek, aldiz, eskolak oztopatzen dituzte (bai ikasleen, bai irakasleen arabera). Horrez gain, gertatu izan direnean, gehienetan konponbidea ez da topatu, 7. grafikoan ikusten den bezala. ${ }^{4}$

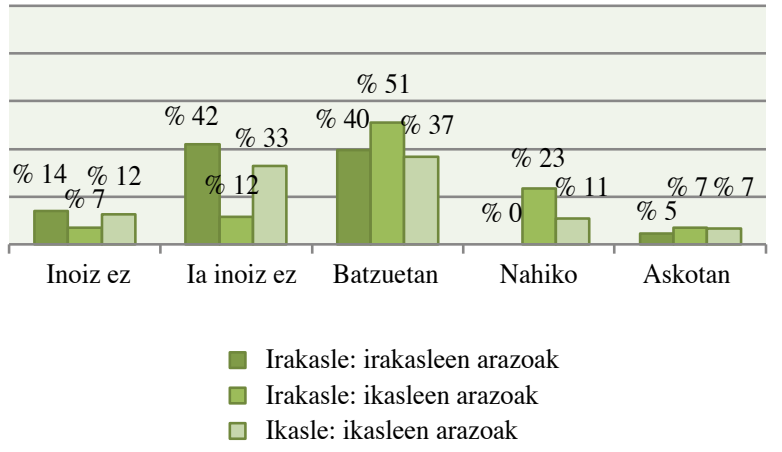

\begin{tabular}{ccc}
\hline Itema & Batezb. & $\begin{array}{c}\text { Desb. } \\
\text { tipikoa }\end{array}$ \\
\hline Ir.6 & 2,4 & 0,90 \\
Ir.7 & 3,12 & 0,96 \\
Ik.8 & 2,67 & 1,05 \\
\hline
\end{tabular}

\section{Arazoak etxeko baliabideekin eskolak edo plataformaren erabileraren oztopatzea Irakasle-galdetegia: 6. eta 8. itemak. Ikasle-galdetegia: 8. itema}

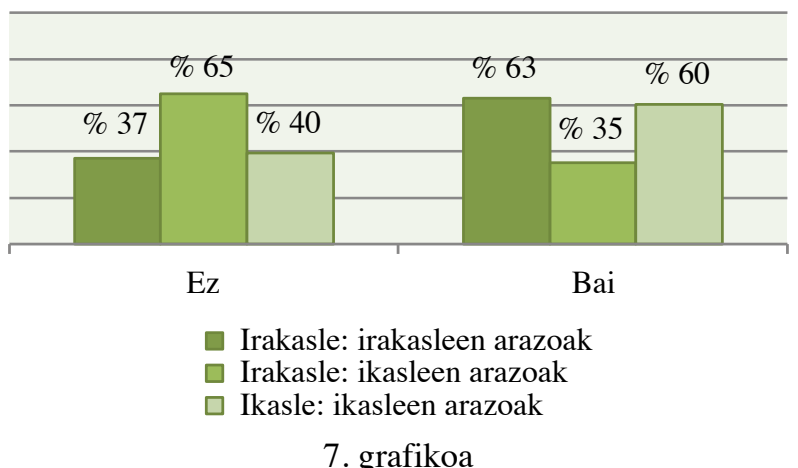

Arazoak egon direnean momentuan konpondu diren. Irakasle-galdetegia: 6b. eta 7b. itemak. Ikasle-galdetegia: $8 b$. itema

\footnotetext{
${ }^{4}$ Likert eskalako erantzuna duten galderetan, batetik bosteko baloreak eman dira erantzunetan. Balio txikieneko erantzuna garafikoan ezkerraldekoa da (bat) eta balio handienekoa eskumaldekoa (bost).
} 


\subsection{Ikaskuntza eta irakaskuntza}

Urrutiko hezkuntzara aldatzean, hezkuntza presentzialeko ordutegia ez da mantendu, orain murriztu da eskola kopurua (ikasle-galdetegia: 11), salbuespen gutxi salbu. Aipatu beharra dago ikasketa-zentro gehienetan ordutegiarenmurrizketa zuzendaritzak agindu duela zuzen-zuzenean. Klase gutxiago izanda ere, ikasleek ikasketetan ematen duten denbora handitu egin da (ikasle-galdetegia: 12), 8. grafikoan ikusten den bezala.

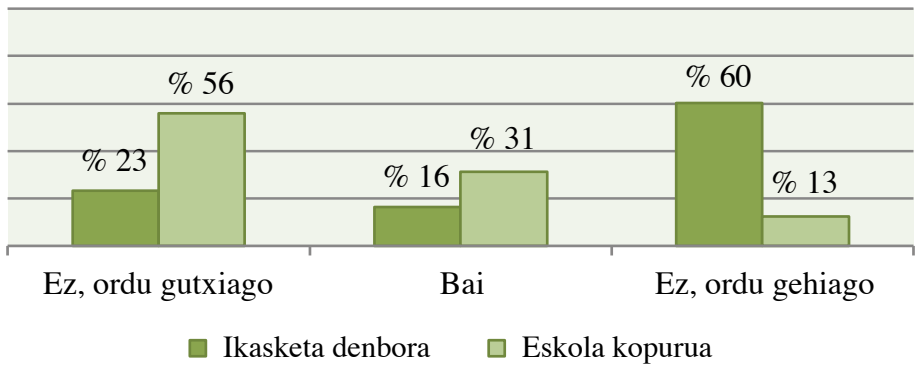

8. grafikoa

Ikasketetan emandako denbora eta jasotako eskola kopurua (talde bideodei) urrutian hezkuntza presentzialarekin alderatuz berdina da? Ikasle-galdetegia: 11. eta 12. itemak

Eskola-orduen murrizketaz gehiago jakin nahian, elkarrizketetan jorratu da gaia. Egoeraren hasieran ez zegoen jarraibiderik, eta irakasle bakoitzak ahal zuena egiten zuen. Gero, Eusko Jaurlaritzaren aginduz, Matematika eta Hizkuntza ikasgaietan izan ezik, gutxienez eskola-orduen heren bat eman behar zen, hau da, lehen astean zehar hiru ordu izanez gero, urrutian irakastean soilik ordu bat eman behar zen. Matematikaren kasuan, lehen astean zehar lau eskola-ordu ematen ziren; orain, ordea, horiek ere murriztu izan dira. Elkarrizketetan, Matematikako irakasle batek adierazi du bere kasuan DBHn zalantzetarako eskola-ordu bakarra eta Batxilergoan bi eskola-ordu egiten duela (beste kideen artean egoera antzekoa da). Beste orduetan suposatzen da ikasleek irakasleak egindako bideotutorialak ikusten, powerpointak, fitxak eta bestelako dokumentuak euren kabuz landu behar dituztela. Arestian azaldutakoa sendotzeko inferentzia baxuko ebidentzia hauek sartu dira:

«Aquí ha sido un sálvese quien pueda, y cada uno está haciendo lo que bien puede. A mí se me ha ocurrido, por yo los conocimientos que tenía, hacerme videotutoriales por YouTube, a otro se le ha ocurrido hacer...» (1. elkarrizketa) 
«Se decidió enseguida, o en los primeros diez días, que [...] como iban a tener menos horas iban a ser de 8.30 a 10.30 y luego de 11.00 a 14.00. Y, vale, lo que yo no veía o lo que no veíamos en nuestro departamento es que no tuviera ningún sentido mantener la primera hora de la mañana como algo presencial, porque... pues porque no, porque los chavales, ahora mismo están teniendo otro ritmo y a mí lo que me interesa es que estén siguiendo la asignatura [...] Entonces, eso [ikasgaiaren saioak] es una hora a la semana.» (2. elkarrizketa)

Lan zamari dagokionez, galdetu zaie irakasleei eskolen prestakuntzari buruz (irakasle-galdetegia: 11. itema) eta ikasleei ikasketa (ikaslegaldetegia: 14. itema) eta lan zamari buruz (ikasle-galdetegia: 15. itema). 9. grafikoan ikusten den bezala, emaitzek erakusten dute nola bai irakasleen, bai ikasleen kasuan zama astunagoa den hezkuntza presentzialekin alderatuz, ikasleen kasuan nabarmentzekoa da batez ere lan zama. Gainera, oharretan gehien errepikatzen den gaia ikasleak lanez gainezka daudelakoa da.

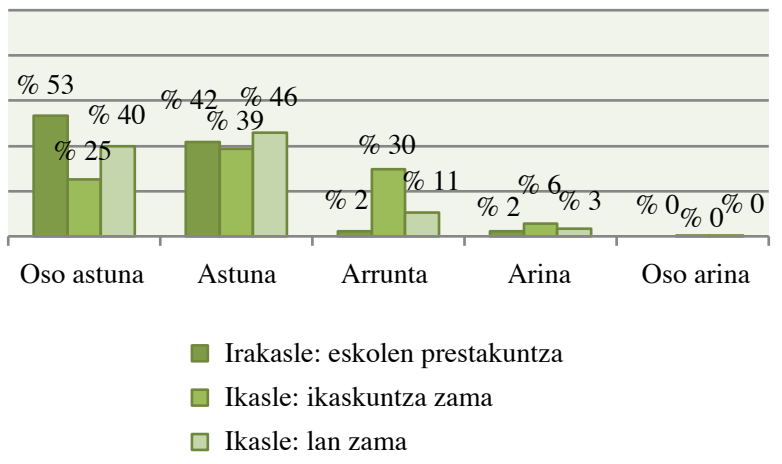

9. grafikoa

\section{Urrutiko eskolen prestakuntza (irakasle), ikasketa eta lan zama (ikasle), hezkuntza presentzialekin alderatuz}

Irakasle-galdetegia: 11. itema eta ikasle-galdetegia: 14. eta 15. itemak

Irakasleen eskolen prestakuntzan eta egokitzapenean sakontzean elkarrizketetan, irakasgaiaren digitalizazioak eta beste irakasleekiko koordinazioak (egon denean) eskatzen duen denbora izugarrizkoa dela azaltzen da. Alde batetik, aldez aurretik irakasgaiaren atal batzuk digitalizatuak eduki arren, urrutian irakastean klasean bertan emandako azalpenak barik edonork ulertzeko gai izateko moldaketak ordu asko eskatzen ditu. Bestetik, urrutian lan egiteko jarduera berriak sortzeak, baliabide digitalen funtzionamendua aztertzeak eta beste irakasleekin urrutian adosteak ere denbora 
asko behar du. Gainera, maila baxuetan ikasleei IKT-en erabilera ere irakatsi behar izan zaie, eta horrek ikasgaiaren edukiak lantzeko denbora murriztu du. Horren harira, inferentzia baxuko ebidentzia hauek aipatu nahi izan dira:

«He gastado muchísimo tiempo en preparar la asignatura, en claro, ahora ya no puedo corregir, digamos en clase, preparar todos los ejercicios, hacerlos de principio a fin, súper claro, para que cualquier persona lo puede entender. Bueno, sí, una locura, muchísimo trabajo» (1. elkarrizketa)

«Pues lo que ellos no sabían, ha tenido ha tenido que ser explicado en las sesiones de Meet. Bueno, pues tenéis que abrir el documento así, luego tenéis que cerrarlo, tenéis que enviarlo de esta forma, me va a llegar a mí, yo os puedo mandar las correcciones... Esa historia ha sido, invertir tiempo en enseñarles a ellos a hacerlo.» (2. elkarrizketa)

Urrutiko eskolen erritmoa jarraitu ahal izateko ikasleek euren kabuz lan egiten (bideo tutorialak, informazioa, ariketak eginda... bilatzen) emandako denbora aztertzeko egindako galderaren aurrean (ikasle-galdetegia: 17. itema). 10. grafikoan erakusten denez, euren kabuz egindako lana areagotu egin da.

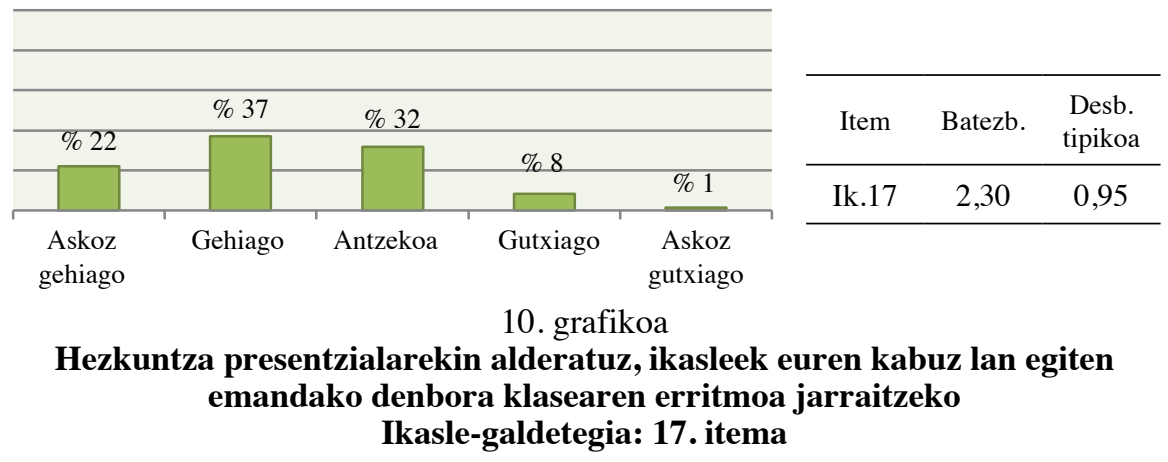

Hortaz, irakasleek emandako eskolak gutxitzean eta ikasleek euren kabuz lan egin behar duten denbora handitzean, ikasleek autonomia izan behar dute euren ikasketak antolatzeko. Hori dela eta, galdera bat egin da ikasleek autonomia erakutsi duten ezagutzeko (irakasle-galdetegia: 23. itema). 11. grafikoan adierazten den bezala, orokorrean ikaslerian autonomia ez da behar bestekoa izan, irakasle gehienen erantzunak (kili-kolo edo txarto) erakusten duenez. 


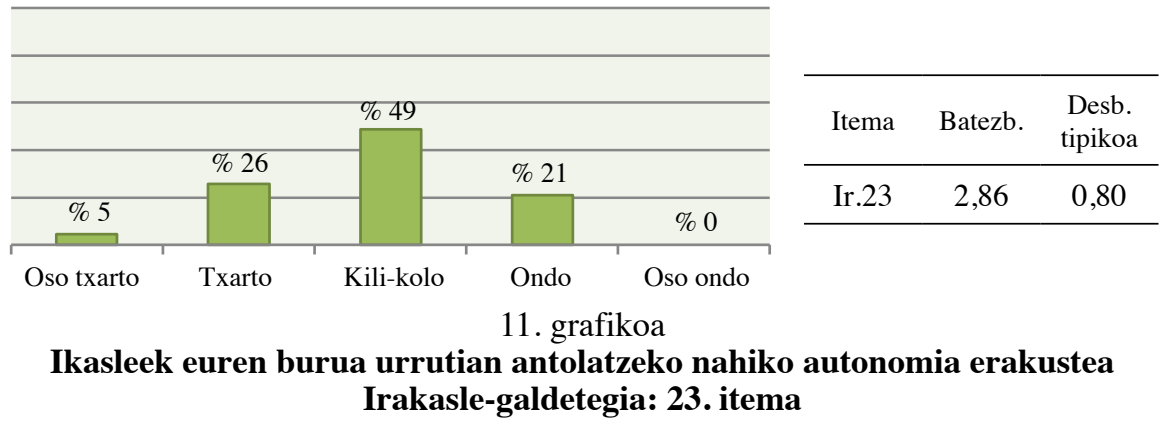

Elkarrizketetan gaia jorratzean, urrutian ikasi ahal izateko autosufizientzia eta autonomia beharrezkoa dela diote irakasleek, baina ikasle askok, adina dela eta, ez du heldutasun maila hori eta denbora hori oporrak balitz bezala hartu dute. Horregatik, absentismoa gora egiten ari dela salatu dute, eta hori egoeraren arazo larriena dela diote. Hala ere, DBHko azken mailan eta Batxilergoan absentismoa ez da hain handia, haien ustean bi arrazoirengatik: kurtso horietan titulo bat lortzea jokoan dagoelako eta kurtso altuetan heldutasun maila handiagoa delako. Egoera inferentzia baxuko ebidentzia hauen bidez ikusten da:

«La educación a distancia sí que requiere una dependencia del..., o sea, una autosuficiencia y independencia del alumnado, que la mayoría de los alumnos, pues con estas edades no tiene porque son muy inmaduros. Y bueno, y pueden aprovechar en este sentido y pensar que es tiempo de recreo o de no hacer nada, como muchos están haciendo; y es el mayor problema que estamos teniendo, que el absentismo pues se está, bueno, multiplicando.» (1. elkarrizketa)

«Yo estoy dando en primero de la ESO Bio-Geo en inglés. Entonces, eso requiere, bueno..., pues que el alumnado..., bueno..., a poder ser venga con todo el temario aprobado y además con un nivel de inglés [...] es alumnado que tiene mucho interés [...] y me consta que hay muchos otros grupos de primero donde la situación no es esa, donde ni siquiera está todo el grupo presente en las clases...» (2. elkarrizketa)

Oraingo egoeran irakasleek eta ikasleek aurrez aurreko harremana izatearen ezintasuna dela eta, irakasleek ikasleen ikasketa-prozesuak egokiro jarraitzen dituztela ziurtatzeak eragina izan duen aztertu nahi izan da (irakasle-galdetegia: 22. itema). Beraz, 12. grafikoan erakusten denez, zailtasunak egon dira ikasleen ikaskuntza prozesuaren egoera jarraitu ahal izateko. Irakasleen harremanei lotutako beste galderak ere egin dira, bai ikasleekiko, bai beste irakasleekiko (irakasle-galdetegia: 14. eta 17. ite- 
mak). Horrez gain, ikasleek euren artean izandako harremanak ere aztertu dira (ikasle-galdetegia: 20. itema).

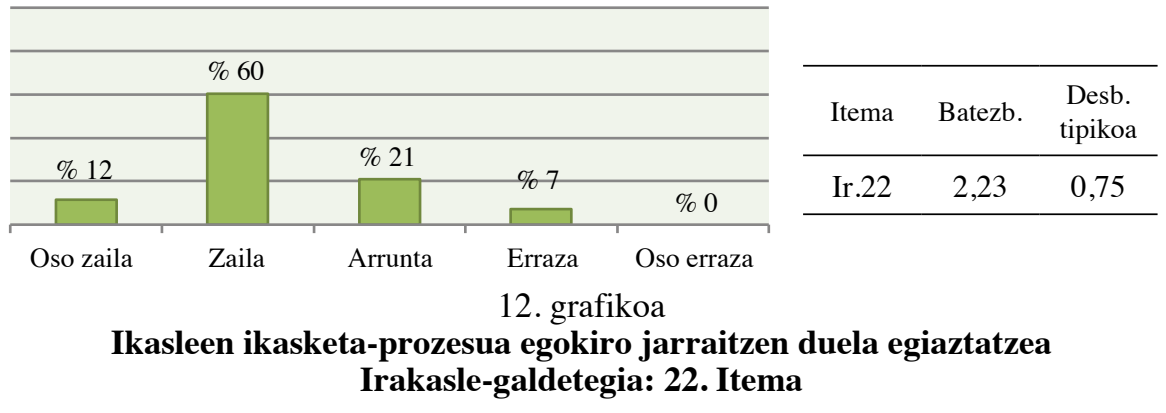

Elkarrizketetan adierazi da ikasleak zuzenean aurrez aurre ez izateak zalantzarik duten ala ez egiaztatzea zailtzen duela, ezin direlako ikasleak ikusi, ezta jakin zertan aritzen diren. Hezkuntza presentzialean, ikasleek euren zalantzak galdetzea zaila zen, baina, urrutian, interesa dutenek soilik galdetzen dute. Orokorrean, eskola presentzialetan parte hartzen ohi ez zutenek urrutian ere ez dute hitz egiten, baina gainera ezin zaie ikusi euren egoera ezagutzeko. Azken finean, interesa erakusten duenarekin eta beharra duela ikusten denarekin komunikazioa mantentzen da ikaskuntza prozesuaren egoera ezagutzeko, baina klasearen alderdi bat babes barik geratzen da. Hurrengo inferentzia baxuko ebidentziak sartu dira arestian esandakoa indartzeko:

«Y que luego, pues, que los alumnos al no estar enfrente, pues se pueden quedar con la duda o no, porque si ya era difícil igual que dentro de clase te consultaran dudas, pues ahora que ni siquiera les ves, ni sabes lo que están haciendo... pues sí que es verdad que el que no se interesa no va a preguntar. [...] tienes comunicación con el que se interesa y con el que ves que lo necesita. Y hay otro sector de clase con el que igual está un poco más, digamos desprotegido, más incomunicado en ese sentido.» (1. elkarrizketa)

«Hay cosas que tú no ves en la videoconferencia, porque además no todo se muestra en la imagen, ¿no? Evidentemente, cuando tú estás en clase hay actitudes de esa persona que estás viendo, de que... sí, parece que te está mirando, pero está en Babia.» (2. elkarrizketa)

Horrez gain, ikasleen ikasketa-prozesuaren garapenean izandako atzeraelikadura ezagutu ahal izateko (irakasle-galdetegia: 18., 19., 20. eta 21. itemak) egindako galderen aurrean bildutako erantzunak aztertzean, urrutiko hezkuntzan atzeraelikadura gutxitzen dela adierazten da, batez ere 
atzerapenei eta hutsei buruzko atzeraelikaduran; egoera 13. grafikoan azaltzen da.

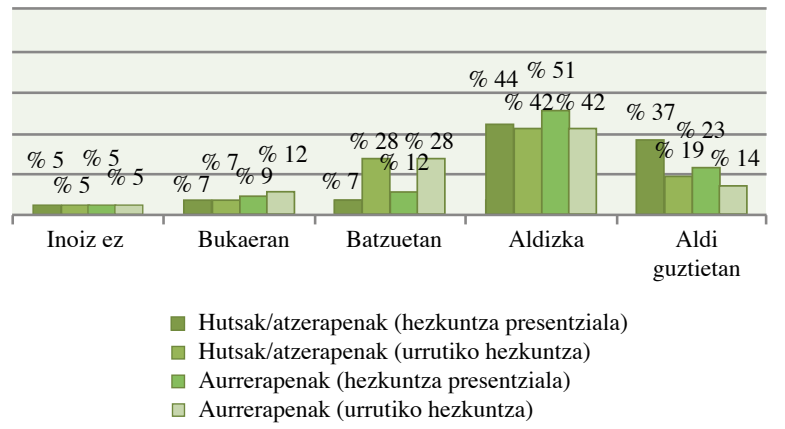

\begin{tabular}{ccc}
\hline Itema & Batezb. & $\begin{array}{c}\text { Desb. } \\
\text { tipikoa }\end{array}$ \\
\hline Ir.18 & 4,02 & 1,08 \\
Ir.19 & 3,63 & 1,02 \\
Ir.20 & 3,79 & 1,06 \\
Ir.21 & 3,49 & 1,03 \\
\hline
\end{tabular}

13. grafikoa

Atzeraelikadura

Irakasle-galdetegia: 18., 19., 20. eta 21. itemak

Hezkuntza presentzialeko irakasgaietan finkatutako helburuak urrutiko hezkuntzara aldatu ostean bete ahal izan diren ezagutu ahal izateko galderan (irakasle-galdetegia: 10. itema), irakasle gehienek kili-kolo edo ondo bete ahal izan direla erantzun dute. Hala ere, urrutiko hezkuntzan gauzatu ahal izateko jakintzagaian aldaketarik egin behar izan den galdetzean, irakasleria gehienak batzuetan aldaketak egin behar izan duela adierazi izan du.

Elkarrizketetan aztertu ahal izan denez, irakasle batzuk atzeraelikadura bermatzen saiatzen dira, baina lehen azaldu bezala gehienetan ikasleriaren alderdi bat babes barik geratzen da.

Irakasgaien berariazko ezaugarriak direla eta ezberdintasun handiak egon daitezkeenez, horien artean urrutiko hezkuntzara egokitzeko zailtasunik izan den aztertu ahal izateko galdera bat planteatu da (irakasle-galdetegia: 13. itema). Jasotako erantzunen arabera, gehien kostatu diren irakasgaiak arlo praktikoak biltzen dituztenak dira, hau da, ebazpen matematikoak, buruketak, laborategia, hizkuntzen mintzamena eta entzumena, marrazketa, gorputz hezkuntza... Irakasgai teorikoenak egokitzea askoz errazago suertatu zaiela adierazi dute, esate baterako, Historia edo Geografia.

Azkenik, ebaluazioa gauzatu ahal izateko erabiliko diren tresnak ere aztertu nahi izan dira (irakasle-galdetegia: 25. itema). 14. grafikoan azaltzen den bezala, zenbait ikasketa-zentrok (\% 11k) oraindik ez du erabaki ebaluazioa nola egingo den. Besteren artean, orokorrean, ikasleen prozesuan zehar egindako zereginak, lanak, izandako parte hartzea... ebaluatuko da. Azterketei dagokienez \% 28k idatzizkoak eta \% 14k ahozkoak egingo direla adierazi du, bien kasuan online bidez, noski. Azterketen harira, aipa- 
tzekoa da egiteko denbora murriztu dela kopiatzea saihesteko; beraz, ikasle batzuek egiteko denbora nahikorik ez dutela diote.

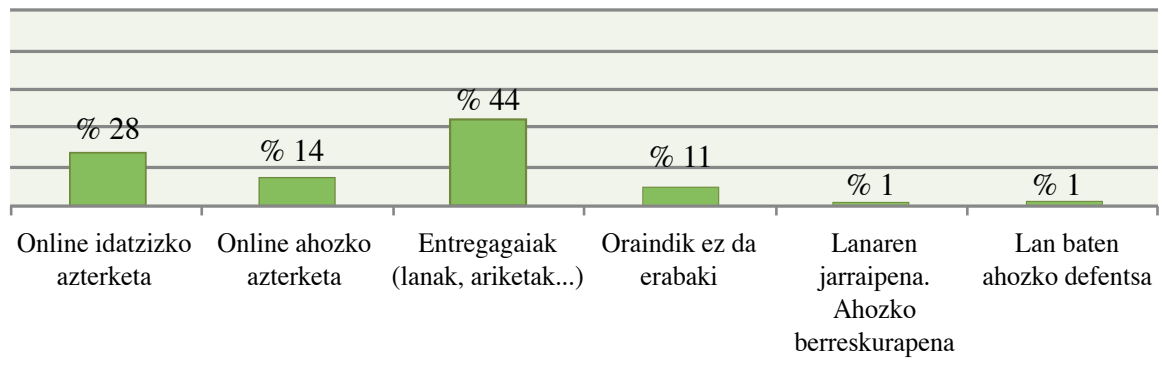

14. grafikoa

Ebaluazio tresnak Irakasle-galdetegia: 25 . itema

Ebaluazioan izandako zailtasun nagusiak ezagutzeko, gaia jorratu izan da elkarrizketetan. Hirugarren hiruhilekoko ebaluazioak, legeak agintzen duen bezala, lehen eta bigarren ebaluazioko kalifikazioa igotzeko balio izango du. Hori dela eta, irakasleek salatzen dute, orain, nahiz eta ikasle bat desagertu eta lanik ez egin, aurreko ebaluazioko kalifikazioa izango dutela eta ezin izango zaiela suspenditu. Gainera, azterketetan asko kopiatzen da eta ia ezinezkoa da antzematea kopiatzen ari diren ala ez; badaude bideak jakiteko erabiltzen duten ordenagailuan zertan aritzen diren, baina aldi berean apunteak, beste ordenagailu bat... erabili ahal dute, baita Whatsapp-en bidez ikaskideekin hitz egin azterketa egiten duten bitartean. Alabaina, letren ikasgaietan ikasleen idazkera maila adierazgarria da, hala nola zenbaitetan gertatu da ikasleak orain arte idazkera maila baxua erakustea eta bat-batean urrutian daudenetik maila oso altua erakustea. Zientziazko ikasgaietan, ikasle askok euren azterketetan akats larri bera errepikatzeak agerian uzten du ez dutela zintzo jokatu. Horretaz gain, kurtsoan zehar azterketetan gehienez sei bat lortzen zuten ikasleek bikainak lortzen dituzte orain. Ondorioz, ikasleen zintzotasuna bermatzeko biderik ez da topatu, eta kopiatu duten frogak izatea ia ezinezkoa da. Ebaluazioari dagokionez, inferentzia baxuko ebidentzia hauek nabarmendu nahiko nituzke:

«Y luego lo que estamos viendo es que a la hora de hacer tanto exámenes, como trabajos, como cualquier cosa es el general [...] se copia mucho, es prácticamente imposible detectar si han copiado o no. Claro, tú no sabes, tú ves lo que muestra esa pantalla, pero dentro de la habitación de ese chaval puede haber un móvil, puede estar el cuaderno con los apuntes, puede haber cualquier cosa, incluso por whatsapp chateando 
con los compañeros; y esto es algo que ha llegado dentro del instituto. No es de estos rumores que se escuchan por cualquier instituto, dentro de nuestro mismo instituto.» (1. elkarrizketa)

«Pero lo cierto es que a veces te das cuenta y detectas casos en los que dices «A ver, mozos, me estáis entregando lo mismo», ¿no? Entonces eso sí que ha habido que tratarlo [...] es la justificación principal para haber reducido el peso [hirugarren ebaluazioarena].» (2. elkarrizketa)

Hori guztia kontuan hartuta, urrutiko hezkuntzaren metodologiaren funtzionamendua irakasleen eta ikasleen ikuspuntu orokorra ezagutu ahal izateko galdera egin da (irakasle-galdetegia: 26. itema; ikasle-galdetegia: 21. itema). Erantzunetan, salbuespenak salbu, bien artean adostasuna dago: urrutiko hezkuntzan desabantaila gehiago daude abantailak baino, 15. grafikoan ikus daitekeen bezala.

\begin{tabular}{|c|c|c|c|c|c|c|c|}
\hline \multicolumn{5}{|c|}{$\% 58$} & & & \\
\hline \multirow{3}{*}{$\% 16^{\%}$} & $\% 40$ & $\% 28$ & & & & & \\
\hline & & & $\% 13$ & & \multirow{2}{*}{ Itema } & \multirow{2}{*}{ Batezb. } & \multirow{2}{*}{$\begin{array}{c}\text { Desb. } \\
\text { tipikoa }\end{array}$} \\
\hline & & & $\% 00$ & $\% 0 \% 0$ & & & \\
\hline \multirow{3}{*}{$\begin{array}{c}\text { Desabantail } \\
\text { pila bat } \\
\text { gehiago, } \\
\text { abantail } \\
\text { baino }\end{array}$} & \multirow{3}{*}{$\begin{array}{c}\text { Desabantail } \\
\text { gehiago, } \\
\text { abantail } \\
\text { baino }\end{array}$} & \multirow{3}{*}{$\begin{array}{c}\text { Ia } \\
\text { bezainbeste } \\
\text { abantail eta } \\
\text { desabantail }\end{array}$} & \multirow{3}{*}{$\begin{array}{l}\text { Abantail } \\
\text { gehiago, } \\
\text { desabantail } \\
\text { baino }\end{array}$} & \multirow{3}{*}{$\begin{array}{c}\text { Abantail } \\
\text { pila bat } \\
\text { gehiago, } \\
\text { desabantail } \\
\text { baino }\end{array}$} & Ir.26 & 2,09 & 0,65 \\
\hline & & & & & Ik.21 & 2,35 & 0,94 \\
\hline & & & & & & & \\
\hline
\end{tabular}

15. grafikoa

Urrutiko hezkuntzaren funtzionamendua Hezkuntza Presentzialekin alderatuz

Irakasle-galdetegia: 26. itema eta ikasle-galdetegia 21. itema

Beste galdera batzuk egin dira irakaskuntza/ikaskuntza prozesuarekin lotutakoak, hala nola jakintzagaiaren egokitzapena, kurtsoaren erritmoa, eskolen antolakuntza, ikasleekiko harremana... (irakasle-galdetegia: 12., 16., 17. itema; ikasle-galdetegia: 13., 16., 18. eta 19. itemak), baita etxean giro aproposa duten ala ez irakaskuntza/ikaskuntza prozesua garatu ahal izateko (irakasle-galdetegia: 15. itema; ikasle-galdetegia: 10. itema).

\subsection{Irakasleria ikasleen ikuspuntutik}

Dimentsio honi buruzko galderak ikasleen galdetegian soilik aurkitu daitezke. Hori dela eta, atalean ikasleen ikuspuntua azalduko da, hain zuzen 
ere, irakasleari buruz. Ikasleen oharrak behin irakurrita, aipatu nahiko nuke irakasleen artean izugarrizko ezberdintasuna dagoela. Ikasle askok euren irakasleen kopuru handi batek ez diela kasurik egiten salatzen dute, eta deslai sentitzen direla. Horiek ez dute ikasleekin komunikazio biderik uzten, eta kexatzen dira lana bidali/agindu besterik ez dutela egiten. Hala eta guztiz ere, euren erantzunetan ez dute erakutsi, irakasleria gehiena ez delako.

Dena den, 16. grafikoan ikus daitekeenez, orokorrean irakasleriaren irisgarritasuna ona izan da (ikasle-galdetegia: 26. itema) eta irakasleek zalantzak argitzeko prest daude. Zalantzak argitu ahal izateko ikasleengana ailegatzeko bideak bilatzen dituzte, banaka zein taldeka. Bideetatik plataformaren txata da ohikoena, baina beste zenbait bide erabiltzen dute: mezu elektronikoa, talde eta banakako bideodeiak, telefonoz deitzea, whatsapp... (ikasle-galdetegia: 23. eta 24. itemak. Horrez gain, azpimarratzekoa da erantzuteko denbora azkarra dela (ikasle-galdetegia: 25. itema).

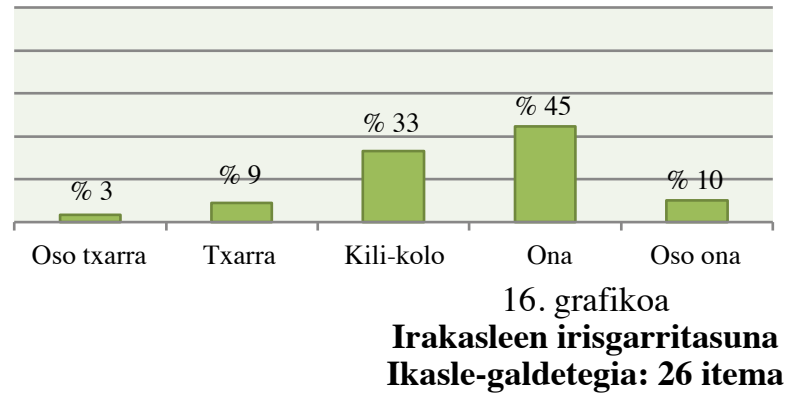

\begin{tabular}{ccc}
\hline Itema & Batezb. & $\begin{array}{c}\text { Desb. } \\
\text { tipikoa }\end{array}$ \\
\hline Ik.26 & 3,49 & 0,92 \\
\hline
\end{tabular}
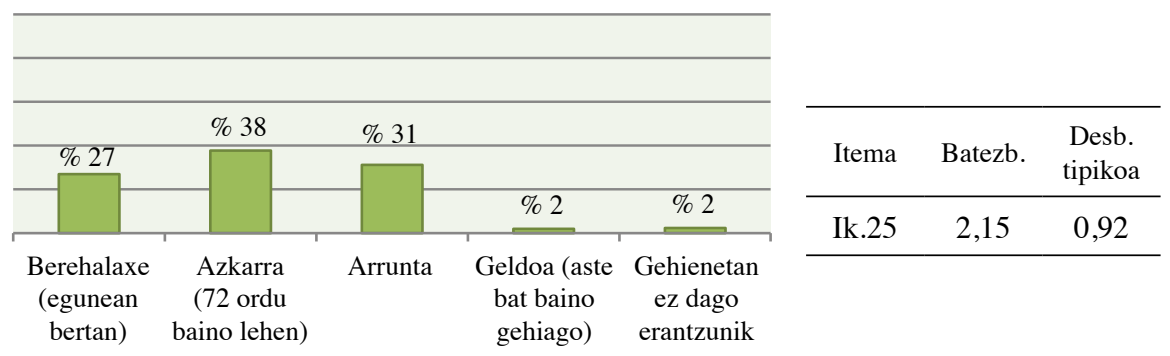

\section{7. grafikoa \\ Irakasleen erantzute-denbora Ikasle-galdetegia: 25. itema}

Hala eta guztiz ere, irakasleek ez dute lortu euren eskoletan (talde bideodeien bidez ematen direnak) didaktika ona izatea. Orokorrean, ikasleek txarra eta kili-kolo artean kokatu dute (ikasle-galdetegia: 22. itema). 
Gainera, edukiak barneratzeko arazoak dituztela adierazten dute oharretan, ikasketa-zentroan bezala azaltzen ez denez, ulertzea zailago egiten zaiela gehitzen dute. Eskolen didaktika kalitatearen beherapena ez da soilik egokitze-prozesuaren zailtasuna, baizik eta ikasleek izorratzen dutelako, oharretan adierazten den bezala.

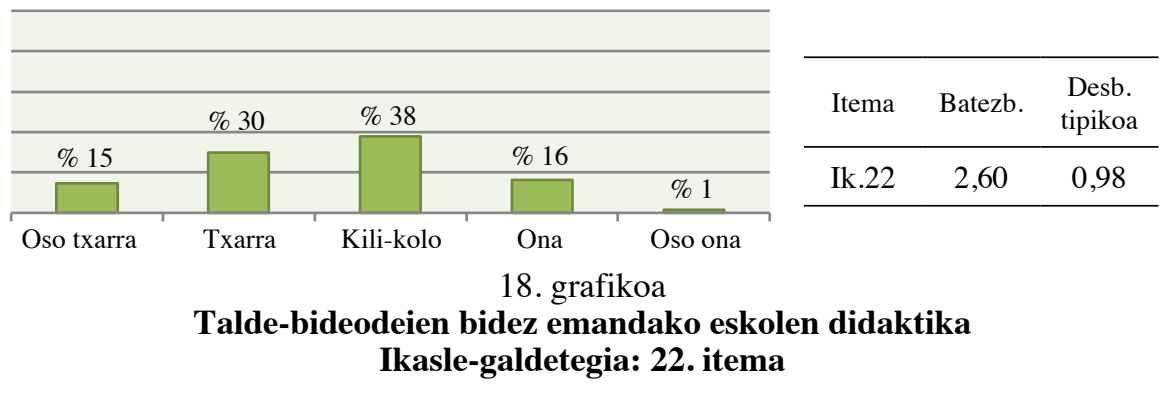

\section{ONDORIOAK}

Hezkuntza presentzialetik urrutiko hezkuntzara bat-batean aldatzeak Bigarren Hezkuntzan izan duen eraginari buruzko datuak bildu eta emaitzak aztertu ostean, hipotesi/galderak ardatz hartuta ateratako ondorioak biltzen dira atal honetan.

Prestakuntza ez da nahikoa izan, ikastetxe gehienetan formatzeko saio bat, bideoak helaraztea, baliabideak ezagutaraztea... izan da jaso duten urrutian irakasteko prestakuntza. Hezkuntza semipresentzialean lan egiten duten irakasleek, aldiz, kurtso osoan zehar jaso dute formazioa, eta hori euren egokitze prozesuan nabari izan da.

Irakasgai baten edukiak urrutiko hezkuntzara egokitzeak planifikazioa behar du, baita beste irakasleekin koordinatzea, eta horrek denbora eskatzen du. Horregatik, irakasleak online erabili ahal den material berria prestatzen eta egokitzen oso lanpetuta egon dira, baita zenbait kasutan pixka bat galduta ere.

Baliabideei dagokienez, ikasketa-zentroak ordenagailua/tablet bat izatea bermatu du, baina Internet konexioaren arloan eskuhartze gutxi egon da. Hala ere, helduentzako Bigarren Hezkuntzako zentroetan ikasleen baliabideak ez dira bermatu. Orduan, baliabideez hitz egitean, ikastetxe arruntetan bermatu da ikasleek urrutiko hezkuntzan partehartzeko beharrezkoa eskura izatea ikasleak sistematik kanpo ez geratzeko, helduentzako ikasketetan izan ezik.

Hezkuntza presentzialeko ordutegia ez denez mantendu, eta irakasleek saio gutxiago egin dituztenez, handitu egin da banakako lana. Urru- 
tiko hezkuntzan ikasten daudenetik ikasleek ikasketetan denbora gehiago eman behar dute. Alde batetik, lan zama asko handitu delako, irakasleek ikasleekin edukitzen ohi zuten saio kopurua murriztu denez, etxerako lan gehiago bidaltzen dituzte, lehen ikastetxean ematen zuten denbora orekatu nahian, baina ikasleen erantzunak behin aztertuta, gehiegizko ikasketa eta lan zama bihurtu da, batez ere lanari dagokionez. Bestetik, ulermen arazoak daude, ikastetxean izandako azalpenak ulertzea errezago egiten zaielako. Hori gertatzen da irakasleek ikasleak ez dituztelako aurrez aurre, euren azalpenak eta erritmoa moldatuz, ikasleen erantzuna ikusita. Gainera, irakasleen hitzetan zaila egiten da ikasleek ikaste-prozesua egokiro jarraitzen dutela egiaztatzea.

Irakasleriak ahaleginak egin ditu egoerara moldatzeko eta ikasleak laguntzeko, eta zalantzak argitu ahal izateko bide ugari erabiltzeko prest egon da eta erantzun denbora, gehienetan, azkarra izan da. Alabaina, ikasleek gutxiago galdetzen dute lehen baino, eta irakasleen esanetan ikasleen gainean egon beharra dago benetan egiaztatzeko ulermen arazoak dauden. Irakasleek ikasleengandik urrun egotean, irakasleentzat zaila da ikasleen lanaren jarraipena egitea eta ulermen mailaren berri izatea. Ikasleak ohituta daude euren alboan pertsona bat izatera zer egin behar duten esaten, baita idatzitako erantzunak zuzenak diren eta zertan okertu diren. Heldu bat gidari izan barik zaila egiten zaie lan egitea. Horrez gain, ratioa txikiago izango balitz, irakasleek errazago antzeman ahal izango lukete ikasleen egoera.

Horrez gain, ikasleek euren hutsei edo atzerapenei buruz jasotako atzeraelikadura asko murriztu da, baita aurrerapenei buruzkoa ere, baina neurri txikiagoan. Irakasle eta ikasleen arteko komunikazioak okerrera egin du, egunero elkar ezin ikusteak zailtzen duelako. Hala ere, aipatu beharra dago zenbait irakaslek ez dutela denbora horretan ikasleekin talde-bideodeirik egin, ikasleekiko zuzeneko harremanik izan..., lanak bidali/agindu baino ez dute egin; hortaz, ikasleek deslai sentitu egin direla salatu dute.

Ikasketa-zentro gehienetan irakasgaien eskola-orduen murrizketa nabaria izan da, zuzendaritzak eta Eusko Jaurlaritzak aginduta gertatu izan dena. Horregatik, ikasleek euren kabuz gehiago lan egin behar izan dute; horretarako, denboraren kudeaketea egokia eta autonomia izatea beharrezkoa da. Horren inguruan lortutako emaitzak behin aztertuta, ikasle gehienek ez dute autonomia eta heldutasun maila ona erakutsi. Gainera, irakasleen kopuru handi batek dio maila altuetako ikasleek hobeto kudeatzen dutela euren denbora. Hori dela eta, urrutian ikastera aldatzeak ikasleen autonomia lantzearengarrantzia agerian jarri du.

Eskola-orduen murrizketak irakasleengan eta ikasleengan lan gehiago eragin du. Irakasleei dagokienez, denbora gutxiago izanda, edukiak emateko zailtasunak dituzte, eta hori konpontzeko beste erak bilatzen dituzte, hala nola beren burua grabatzea bideoetan eta plataforman eskegitzea. Gainera, ikasleek izandako zalantzak banaka galdetzen dituzte plataforma- 
ren txatean, mezu elektronikoz edo bestelako bideez. Beraz, irakasleari mezu asko pilatzen zaizkio, eta banaka erantzun ahal izateko denbora asko eman behar du; gainera, askotan zalantzak antzekoak izaten dira. Hezkuntza presentzialeko ordutegia mantendu izan balitz (ikastetxe batzuetan gertatu dena), eskola-orduan guztien aurrean edukiak eman bitartean (denbora nahikoa izanda) partekatutako zalantzak argitzeko denbora egongo litzateke. Era horretan, ikasleek euren kideen zalantzez aberasteko aukera izango lukete.

Orduan, irakasleen urruneko azalpenak ulertzeko eta barneratzeko arazoak izateagatik, edo irakasleak soilik lanak bidaltzeagatik azalpen barik, gabeziak egon dira. Ulermen gabezia horien aurrean eskolen erritmoa jarraitu ahal izateko ikasleek euren kabuz lanean (bideo tutorialak, informazioa, ariketak eginda... bilatzen) emandako denborak gora egin du. Ikasleak lanez gainezka sentitu dira, hainbeste denbora eman behar izateagatik euren ikasketetan aritzen.

Nabarmendu nahiko nuke hezkuntza presentzialean arduratsuak diren ikasleak urrutian ere halakoak izaten direla, arazo teknikoak egonda ere. Egoera horretan, ordea, motibazio eza edo bestelako behar bereziak dituztenak galdu egiten dira. Horiek irakasleari kasurik ez egiteko ordenagailua amatatu besterik ez dute behar, eta berriro hauen arreta lortzea oso zaila da. Ikasleen galera ikasketa-zentro askotan gertatzen ari da, irakasle askok salatzen dute saio birtualetara ikasle gutxiago konektatzen direla presentzialetara joaten zirenak baino. Hezkuntza semipresentzialean ere, egoera bera aurkezten da; lehenengo saio presentzialak birtual bihurtzean ikasle gutxiagok parte hartzen dute. Motibazio eza edo behar bereziak dituzten ikasleen jarraipena ezinbestekoa da, eta horiek bultzatzea presentzialean zaila bada, urrutian ia ezinezkoa.

Horretaz gain, edukien irakaskuntza alde batera utzita, irakasle askoren kezka urrutian lan egiteak gizatasuna kentzea eragiten duela da. Ikasleak egunero ikustea, haiekin hitz egitea, bizipenak partekatzea... Bigarren Hezkuntzaren alderdi garrantzitsua da: ikasleei laguntzea ikasketetan eta pertsonalki, baita haiengandik ikastea ere. Zoritxarrez, arlo hau ezin izan da mantendu urrutian irakastean.

Hori guztia kontuan hartuta, orokorrean aurrez aurreko komunikazioa ez izatea oztopoa izan dela erakusten da.

IKT-en erabilera ezinbestekoa bihurtu da urrutian ikaste/irakaste prozesua aurrera eraman ahal izateko. Nahiz eta aldez aurretik erabiltzera ohituta ez egon plataforma bat erabiltzera edo bestelako IKT baliabideetara, ikasleak ondo moldatu dira. Haatik, arloaren alde txarra arazo teknikoak dira. Irakasleen etxeko baliabideak direla eta sortutako arazoak konpontzeko bideak errazago aurkitu dira eta, beraz ez dute eskola oztopatu. Ikasleen arazo teknikoak, ordea, eskoletan eragin kaltegarria izan dute, gertatu izan direnean momentuan konpondu ahal izatea zaila izan da. Dena den, arazo teknikoak agertzea lan gehiago bihurtzen da, irakasleak kasu bakoi- 
tzera moldatu behar du konpontzeko, bideak proposatu ikasleei, errepikatu esandakoa... eta hori egiten den bitartean eskola gelditu behar da, edo, bestela, aurrera jarraitu behar da arazo teknikoak izandako ikaslea alde batera utzita. Horren harira, irakaskuntza prozesuan erabilgarri diren IKT zenbait baliabide ez dira doakoak, eta ikastetxe batzuek ez dutela honako arlo digitalean inbertitzen adierazi da.

Urrutiko hezkuntzan etxea ikaste/irakaste-tokia bihurtu da, eta horretan dagoen giroa ikasleen eta irakasleengan izandako eragina aztertzean persona batetik bestera desoreka handia dagoela egiaztatu da, baina orokorrean giroa ona da, eta distrazio eta etete gutxi izan dira. Hala ere, ikastetxean denek giro aproposa dute eta etxean batzuentzat etete gehiegi daude. Dena den, egoera ikertu ostean, orokorrean etxeko giroak ondorio kaltegarririk ez duela izan azpimarratu behar da.

Ebaluazioaren arloan, kalitatezko ebaluazioa egitea urrutitik oso zaila da, ariketak, lanak, aurkezpenak eta bestelako zereginak urrutira egokitu ahal dira. Halere, urrutiko azterketak eta ebaluazioa egitea oso zaila da. Ahozko azterketak gauzatu daitezke, baina denbora asko behar da banan-banan ikasle guztiei egin ahal izateko. Idatzizko azterketetan ikasleen zintzotasuna bermatzeko bideak erabiltzen saiatu arren (azterketa eredu asko ez kopiatzeko, denbora gutxi besteekin hitz egiteko denbora ez izateko, ikasleen pantaila ikusi ahal izateko programak...), irakasleen esanetan ezin da ziurtatu.

Arestian azaldu den bezala, datuak bildu eta emaitzak aztertu ostean, irakasleek eta ikasleek bizi izandako egoera euren ikuspuntutik ezagutu izan da, baita ondorioak atera ere. Dena den, aurreko paragrafoetan azaldutatakoa euren erantzunen arabera eraikitako egia da. Horrekin esan nahi dena da irakasleek eta ikasleek adierazitakoa iritzi bat dela; beraz, ez da zertan izan egia absolutu bat.

\subsection{Urrutiko hezkuntza hobetzeko proposamenak Bigarren Hezkuntzan}

Bigarren Hezkuntzan izandako egoera ikertuta, urrutiko hezkuntza mantendu behar izango balitz, edo beste konfinamendu bat egotekotan berriro martxan jarri behar izango balitz, aldaketak egin beharko lirateke kalitatezko hezkuntza bermatu ahal izateko.

1. Prestakuntza: irakasleek kalitatezko formakuntza jaso behar dute urrutian irakasteko. Horretan urrutian erabili ahal diren metodologia, baliabideak eta abar ezagutarazi beharko zaizkie, baita ikasleekiko atzeraelikadura nola egin ere.

2. Planifikazioa: urrutian irakasteko planifikazioa prestatu behar da, edukiak lantzeko eta helburuak betetzeko urrutian garatu ahal diren jarduerak prestatuz eta beste irakasleekin koordinatuz. 
3. Hezkuntza presentzialeko ordutegi berdina (eskola-ordu kopurua): ikastetxeko ordutegia mantendu behar da, lehen zuten eskola kopuru berarekin. Irakasleen gida eta laguntza egunero zuzenean izatean, birtualki izan arren, irakasleen eta ikasleen arteko komunikazioa hobetuko litzateke. Horrela, ikasleen erritmora moldatzea posible izango litzateke, baita ulermen eta barneratze arazoak murriztu, zalantzetarako denbora utziz saio guztietan. Ondorioz, ikasleek ez lukete hainbeste denbora eman behar euren kabuz informazioa, bideo tutorialak, ariketak eginda... bilatzen eta lan zama ere orekatuagoa izango litzateke.

4. Derrigorrezko saioak: ikasleak derrigortzea online saioetan egotera eta protokolo bat prestatzea hori gertatzen ez bada nola jokatu erabakitzeko. Gainera, saioetan kamera piztuta izanez gero, aurpegian ulermen arazoak antzeman ahal dira.

5. Familien inplikazioa: familien inplikazioa beharrezkoa da, haiekin bilera bat izatea beharrezkoa da ikasleen ikaskuntza prozesuan parte hartzeko, haiek direlako ikasleen alboan daudenak ikasketaprozesua urrutian garatzean.

6. Motibazio eza eta behar bereziko ikasleak ez galtzea: motibazio eza edo behar bereziak dituzten ikasleen jarraipena ezinbestekoa da, eta horiek sistematik kanpo ez geratzeko aldaketak egin behar dira. Orain urrutiko ikaskuntzan erabilitako ereduan bermatzen ez dena. Hortaz, ikasle horien familiarekin adostasun batera ailegatu behar da, edo programaren bat martxan jarri etxeratze-egoera berriro gertatzen bada hezkuntza-sistematik kanpo gera ez daitezen.

7. Autonomia: ikasleak autonomo izatea sustatu behar da. Urrutian ikastera aldatzeak ikasleen autonomia lantzearen garrantzia agerian jarri du. Beraz, ikasleen gabezi hori ezagututa, aurrerantzean ikasleen autonomiaren garapena sustatzeak helburu bat izan beharko luke, erabilgarria izango dena ez soilik euren bizitza akademikoan, baizik eta euren bizitzaren arlo guztietan.

8. Ikaslerik ez geratzea sistematik kanpo: Bigarren Hezkuntzan ikasten ari diren helduek ez dute baliabiderik jaso ikaskuntza prozesua aurrera eraman ahal izateko. Ikasketa-zentro horietako ikasleak sistematik kanpo ez geratzea ez da bermatu, eta, irakasleek ezagutarazi duten bezala, eskoletan parte hartzen zuen ikasle kopurua murriztu egin da. Hori dela eta, ikasle horiek, ikasketa -zentro arruntekoek bezala, beharrezko baliabideak eskura izatea bermatu behar da, ikasketak bertan behera ez uzteko. Azken finean, ikasle helduek ikasketak bertan behera uzteko aukera gehiago daude, eta ikastetxera berriro bueltatzeko ahalegina egin ostean penagarria izango litzateke berriro ikasketak uztea baliabideak ez izategatik. 
9. Ebaluazioa: kalitatezko ebaluazioa egin ahal izateko, azterketa idatziak presetzialki egiteko bide bat topatu behar da, edo beste ebaluazio tresnak bilatu.

Hezkuntza presentzialera bueltatu ahal izatean, ez da bizi izandako egoera ahaztu behar. Urrutiko hezkuntzan erabili den metodologiak desabantailak ditu, baina horri esker hezkuntzan dauden gabeziak azaleratu dira. Horretaz gain, egokitzapen prozesuan lagungarri diren hainbat baliabide ezagutu dira; beraz, hezkuntza presentzialera bueltatzean ez lirateke ahaztu eta baztertu behar, ohiko hezkuntzaren osagarri gisa erabili baizik.

\section{IKERKETAREN MUGAK}

Ikerketa honen garapenean zehar izandako mugak datuen bilketan gertatu dira, bai galdetegietan, bai elkarrizketa erdi-egituratuetan.

Galdetegiei dagokionez, ikasleen kasuan ikasle-talde guztietako partaideak batuz gero berrehun eta bost erantzun jaso dira; Irakasleen kasuan, aldiz, berrogeita bi izan dira. Halarik ere, hobe izango litzateke galdetegi gehiago jaso izan balira.

Kontuan hartu beharra dago bizi izandako egoera eta irakasleekin harremanetan jartzeko zailtasunak. Horretaz gain, zenbait ikastetxe eta irakasle ikerketetan parte hartzeko prest ez egotea oztopo handi bat izan da. Gainera, irakasle batzuk bizi izandako egoeragatik lanez gainezka egotean, parte hartzeko denborarik ez zutela ere argudiatu dute. Hala eta guztiz ere, galdetegien bidez lortutako datuak Euskal Autonomia Erkidegoko egoera aztertzeko baliagarriak izan dira.

Elkarrizketa erdi-egituratuei dagokienez, galdetegiak bete dituzten irakasleen artean haiek egiteko prest daudenak lortzeko zailtasunaren aurrean, bi edo hiru irakaslearekin osatzea erabaki da. Behin elkarrizketa horien datuak bilduta, emaitzak aztertu dira ondorioak ateratzeko. Lehen bezala, irakasle gehiagoren elkarrizketak lortu ahal izango balira, hobe izango litzateke.

Laburbilduz, datuak biltzeko tresnen bidez lortutako lagina mugatua izan arren, emaitzak eta haien ondorioak esanguratsuak dira. Hala eta guztiz ere, datu gehiago bildu ahal izan balitz, ikerketa lana biribilagoa izango zen, bai galdetegiei, bai elkarrizketei dagokienez.

\section{ERREFERENTZIAK}

Bates, T. (1999). La tecnología en la enseñanza abierta y la educación a distancia. Trillas.

Battenberg, R. W. (1971). The Boston Gazette. March 20, 1728. Epistolodidaktika, 1, 44-45. or. 
Bisquerra, R. (2009). Metodología de la investigación educativa. La Muralla.

Camacho, A. (2019). E-learningaren iragana, oraina eta geroa: ohar batzuk. In Iruskieta, M., Maritxalar, M., Arroyo, A. eta Camacho, A. (arg.) IKTak eta konpetentzia digitalak hezkuntzan (117-128 or.). Euskal Herriko Unibertsitateko Argitalpen Zerbitzua.

Clark, J. J. (1906). The correspondence school - Its relation to technical education and some of its results. Science, 24(611), 327-334. or.

Eitb-ko erredakzioa (2020-03-09). Gasteizko eskola eta hezkuntza zentro guztiak itxi dituzte, martxoaren 23ra arte. Eitb albisteak. https://www.eitb.eus/eu/ albisteak/gizartea/osoa/7086214/gasteizko-eskola-eta-hezkuntza-zentroguztiak-itxi-dituzte-martxoaren-23ra-arte/

Eitb-ko erredakzioa (2020-03-11). Arabako eta Balmasedako ikastetxe guztiak itxi dituzte. Eitb albisteak. https://www.eitb.eus/eu/albisteak/gizartea/ osoa/7093249/arabako-eta-balmasedako-ikastetxe-guztiak-itxi-dituzte/

Eitb-ko erredakzioa (2020-03-12). Eskolak bertan behera geratuko dira bihartik EAEn. Eitb albisteak. https://www.eitb.eus/eu/albisteak/gizartea/ osoa/7094648/eaeko-ikastetxe-guztiak-itxiko-dituela-iragarriko-du-euskojaurlaritzak/

Eitb-ko erredakzioa (2020-03-14). Sanchezek gaur alarma egoera ezarriko du koronabirusa geldiarazteko. Eitb albisteak. https://www.eitb.eus/eu/albisteak/ gizartea/osoa/7097388/espainian-alarma-egoera-deklaratu-du-2020ko-martxoaren-13an-koronabirusagatik/

García, L. (1999). Historia de la educación a distancia. Revista Iberoamericana de educación a distancia, 2(1).

García, L. (2002). La educación a distancia. De la Teoría a la Práctica. Ariel.

Vela, P. A., Ahumada V. R. eta Guerrero, J. H. (2015). Conceptos estructurantes de la educación a distancia. Revista de Investigaciones UNAD, 14(1), 115149. or.

Hezkuntza eta Lanbide Heziketa Ministerioa (2019). Estadísticas de la Educación, enseñanzas no universitarias: alumnado. https://www.educacionyfp.gob.es/ servicios-al-ciudadano/estadisticas/no-universitaria/alumnado/matriculado. html

Hezkuntza eta Lanbide Heziketa Ministerioa (d. g.). Estudiar Bachillerato en España: Dónde estudiar. http://www.educacionyfp.gob.es/contenidos/estudiantes/bachillerato/donde-estudiar.html

Hezkuntza eta Lanbide Heziketa Ministerioa (d. g.). Estudiar Educación Secundaria Obligatoria en España: Dónde estudiar. http://www.educacionyfp.gob.es/ contenidos/estudiantes/educacion-secundaria/donde-estudiar.html

Holmberg, B. (1995). The evolution of the character and practice of distance education. Open Learning: The Journal of Open, Distance and e-Learning, 10(2), 47-53. or.

Holmberg, B. (2005). Theory and practice of distance education. Londres: Routledge.

Institutu Cervantes (d.g.). Diccionario de términos clave de ELE: Consultas en Internet. https://cvc.cervantes.es/Ensenanza/biblioteca_ele/diccio_ele/indice.htm

King, F. B., Young, M. F., Drivere-Richmond, K., eta Schrader, P. G. (2001). Defining distance learning and distance education. AACE journal, 9(1), 1-14. or. 
Klaudio Harluxet Fundazioa (2001). Harluxet: Euskal Hiztegi Entziklopedikoa. Elkarlanean.

Lamí, L. E., Pérez, M. G., eta Rodríguez, M. E. (2016). Las herramientas de comunicación sincrónica y asincrónica en la clase presencial. Revista Conrado, 12(56), 84-89. or.

López, S. (2020-03-09). Cierre de todos los colegios de Vitoria y el campus alavés de la UPV durante 15 días. El Diario Vasco. https://www.diariovasco.com/sociedad/salud/labastida-cierra-colegios-20200309080615-nt.html

Lukas, J. F., eta Santiago, K. (2016). Hezkuntza-ebaluazioa. Euskal Herriko Unibertsitateko Argitalpen Zerbitzua.

Martín, Ó. (2013). La satisfacción del usuario en la enseñanza virtual: el caso del sistema universitario andaluz. Doktorego tesia. Universidad de Granada, DIGIBUG.

Martínez, C. H. (2008). La educación a distancia: sus características y necesidad en la educación actual. Educación, 17(33), 7-27. or.

Moore, J. L., Dickson-Deane, C., eta Galyen, K. (2011). e-Learning, online learning, and distance learning environments: Are they the same?. The Internet and Higher Education, 14(2), 129-135. or.

Phipps, R. A., eta Merisotis, J. P. (1999). What's the difference? A review of contemporary research on the effectiveness of distance learning in higher education. The Institute for Higher Education Policy.

Real Academia Española (2019). Diccionario de la Lengua Española (23.3. edizio elektronikoa).

Repáraz-Abaitua, C., Sobrino, A. eta Naval, C. (2004). Cuestionario de satisfacción con la formación online. In M.A. Fortea eta L. Lapeña (arg.), Hacia una docencia de calidad: políticas y experiencias. Publicaciones de la Universitat Jaume I.

RTVE-ko erredakzioa (2020-04-04). ¿Qué se sabe del coronavirus de Wuhan?. RTVE albisteak. https:/www.rtve.es/noticias/20200405/se-sabe-del-nuevocoronavirus-china/1996067.shtml

Santoveña, M. S. (2010). Cuestionario de evaluación de la calidad de los cursos virtuales de la UNED. Revista de Educación a Distancia, 25. 